\title{
GROUND BEETLES (COLEOPTERA: CARABIDAE) FOUND IN CONVENTIONAL POTATO CULTIVATIONS (SOLANUM TUBEROSUM L.) IN THE SUBCARPATHIAN REGION
}

\author{
CZERniAKOWSKI, Z. W. - OLbRYCHT, T. - KONIECZNA, K. ${ }^{*}$ \\ Uniwersity of Rzeszów, Faculty of Biology and Agriculture, Department of Agroecology \\ Ćwiklińskiej 1, 35-601 Rzeszów, Poland \\ ${ }^{*}$ Corresponding author \\ e-mail: vespillo1@gmail.com; phone: +48-607-434-673 \\ (Received 24 $4^{\text {th }}$ Jul 2019; accepted $8^{\text {th }}$ Jan 2020)
}

\begin{abstract}
The aim of this research was to identify the species composition and quantitative and qualitative structure of ground beetles inhabiting conventional potato cultivations. The study was conducted over the 2008 and 2011-2013 period in eleven localities in the Subcarpathian region (Podkarpacie). Beetles were captured using Barber pitfall traps. A total of 7406 beetles were caught, which were classified in 29 genera and 54 species. Small zoophages proved to be the most numerously represented trophic group, whereas the species that were caught as greatest numbers at the study sites were as follows: Harpalus rufipes, Pterostichus melanarius, and Poecilus cupreus. The obtained results demonstrate that anthropogenic factors affect both the trophic structure of ground beetle populations and their habitat preferences. At the same time, species with wide ecological tolerance and lower susceptibility to anthropogenic pressure were promoted. It was also shown that the maintenance and appropriate management of diverse biocoenoses in agricultural space contribute to increased diversity of Carabidae found in agrarian areas.
\end{abstract}

Keywords: carabids, cropping, species diversity, SE Poland

\section{Introduction}

Beetles of the ground beetle family (Carabidae) are an important group of animals found in agrocenoses. Among them, omnivorous or partially herbivorous species can be distinguished (Clark et al., 1993; Kromp, 1999), but in the majority of cases representatives of Carabidae belong to non-specialized zoophages, thus being a factor regulating the numbers of some herbivorous species (Thiele, 1977). These active predators feed on both invertebrates (Mollusca) and phytophagous representatives of different taxa of the class Insecta (Coleoptera: in particular, Chrysomelidae, Lepidoptera, and Hemiptera, including Aphididae and Thysanoptera) (Wiltshire and Hughes, 2000; Sunderland, 2002; Schmidt et al., 2003).

The lack of food specialization of zoophagous carabids is manifested both in the wide species spectrum for potential victims and in the possibility of hunting different pests at different developmental stages (pre-imagoes and imagoes). At the same time, it should be noted that herbivorous carabids (obviously excluding phytophagous species that cause economic damage) can reduce weed density from 60 to $80 \%$ during one growing season (Ward et al., 2011). Therefore, we can consider Carabidae to be particularly valuable organisms in the aspect of controlling pests of cultivated plants.

For growing potato (Solanum tuberosum L.), the most dangerous pest is the Colorado potato beetle (Leptinotarsa decemlineata Say). Under field conditions, natural enemies can contribute to weakening a Colorado potato beetle population by $23-78 \%$ by destroying eggs, young larvae, and adult beetles (Karg, 1976; Sosnowska et al., 2009). The most important Carabidae species that are mentioned as predators significantly 
reducing Colorado potato beetle numbers include Pterostichus melanarius (Ill.), Poecilus cupreus (L.), and Harpalus rufipes (De Geer) (Koval, 1999; Oberholzer and Frank, 2003). Observations on the carabid fauna of potato cultivations have been conducted, among others, in Latvia (Bukejs, 2009), Russia (Cinītis, 1962; Koval and Guseva, 2008), Russia, Moldova, and Ukraine (Koval, 2012), Finland (Kinnunen and Tiainen, 1999), Austria (Kromp, 1990; Traugott, 1998; Juen et al., 2003), and Romania (Varvara, 2010). In the United States, such observations have been conducted, among others, by Zhang et al. (1998), Werling and Gratton (2008), and Rondon et al. (2013).

In Poland such research has been carried out predominantly in the northern and western parts of the country, in the following Voivodeships: Zachodniopomorskie (Fedorko, 1983), Warmińsko-Mazurskie (Kosewska et al., 2008), Wielkopolskie (Nijak, 2005; Kosewska and Nijak, 2012; Nijak et al., 2014), Dolnośląskie (Jasiński et al., 2015), and Świętokrzyskie (Huruk, 2006). The studies regarding the ground beetle fauna inhabiting potato cultivation $\mathrm{s}$ in south-eastern Poland that have been published thus far are only fragmentary (Szewkienicz and Olbrycht, 2012; Konieczna et al., 2015). Therefore, this publication presents more detailed results of a study on the species composition, quantitative structure, and ecological characteristics of ground beetles inhabiting conventional potato cultivation $s$ in this region for the first time.

\section{Material and Methods}

\section{Study sites}

Observations on the species composition and numbers of ground beetles (Col., Carabidae) were conducted in eleven localities of south-eastern Poland during the 2008 and 2011-2013 growing seasons (Fig. 1). The study area comprised conventional potato (Solanum tuberosum L.) cultivations and the research covered thirteen sites. Samples collected in 2008 related to the sites in: Cierpisz, Olimpów, and Przeworsk. In Słonne, the selected site was investigated in 2011. Samples collected from potato cultivations in two growing seasons (2012-2013) related to the sites in Pakoszówka and Wiśniowa. In 2013 the sites in the following localities were studied: Drohojów, Kosina, Olszynka, Równia, and Wacławice.

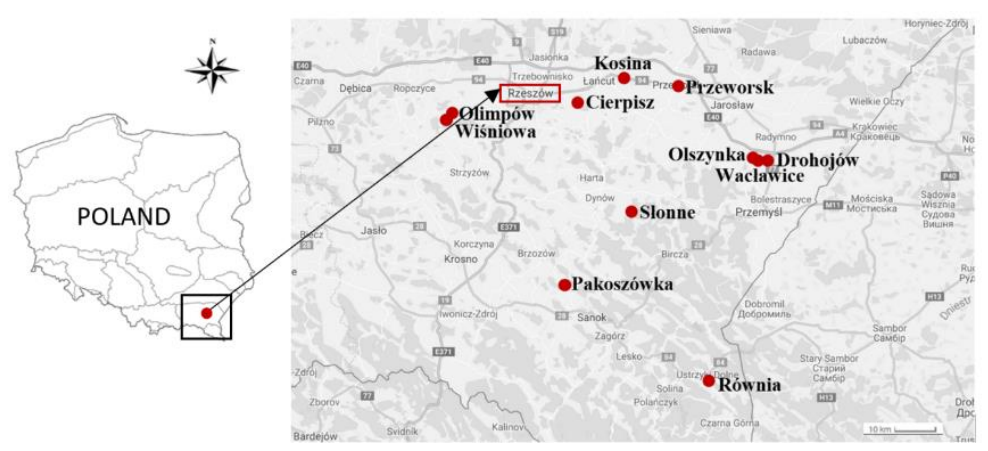

Figure 1. Location of study sites (the authors' own figure based on www.lepidoptera.eu/utm)

In a large majority of cases, potato cultivations where observations were conducted were surrounded by diverse habitats. Apart from intensively agriculturally used areas, such as cultivation fields, areas with lower agronomic pressure (meadows and pastures) 
and wooded areas (field trees and shrubs, forests) can be distinguished among them. The description of biocenoses adjacent to the potato cultivation $\mathrm{s}$ and areas of the study sites (in ares) are shown in Table 1, whereas the geographical characteristics, soil quality classes as well as a list of potato cultivars and cultivation protection products used in their cultivation are presented in Table 2.

Table 1. Areas of the study sites (in ares) and characteristics of biocenoses adjacent to potato cultivations at study sites

\begin{tabular}{c|c|c|c|c}
\hline Site No. & Location & Year & Area [ares] & Adjacent habitats \\
\hline 1 & Cierpisz & 2008 & 25 & oats cultivations, forest \\
2 & Olimpów & 2008 & 30 & cereal cultivations, tree stands \\
3 & Przeworsk & 2008 & 30 & wheat cultivations, meadow \\
4 & Słonne & 2011 & 12 & agriculturally used areas, shrub stands, forest, meadow \\
5 & Pakoszówka & 2012 & 20 & agriculturally used areas, meadow \\
6 & Wiśniowa & 2012 & 15 & agriculturally used areas, forest, meadow \\
7 & Drohojów & 2013 & 51 & meadows, tree stands, river \\
8 & Kosina & 2013 & 50 & maize, rye and wheat cultivations \\
9 & Olszynka & 2013 & 70 & oilseed rape and potato cultivations \\
10 & Pakoszówka & 2013 & 19 & pastures, tree stands \\
11 & Równia & 2013 & 15 & shrub stands, pastures, meadow, stream, ponds \\
12 & Wacławice & 2013 & 60 & cereal cultivations, walnut plantation, forest \\
13 & Wiśniowa & 2013 & 20 & forest, meadows, cultivation fields \\
\hline
\end{tabular}

Table 2. Geographical characteristics, soil quality classes as well as a list of potato cultivars and cultivation protection products used in their cultivation at study sites

\begin{tabular}{|c|c|c|}
\hline \multicolumn{2}{|c|}{$\begin{array}{c}\text { Study site No. / GPS coordinates / } \\
\text { variety / soil classification }\end{array}$} & \multirow{2}{*}{$\begin{array}{c}\text { Fertilizing and crop protection products * } \\
\text { thiamethoxam } 250 \mathrm{~g} / \mathrm{kg}(25 \%), \text { MCPA-300 } \mathrm{g} / \mathrm{l}+\text { dikamba-40 g/l, } \\
\text { ammonium sulphate }(28 \mathrm{~N})\end{array}$} \\
\hline 1 & $\begin{array}{l}\text { N:509’33”, E:2142’54” } \\
\text { Bila / IV b }\end{array}$ & \\
\hline 2 & $\begin{array}{l}\text { N:50o0'20", E:21o46'2" } \\
\text { Atol, Ibis / n. d. }\end{array}$ & metribuzin, mancozeb $680 \mathrm{~g} / \mathrm{kg}+$ cymoxanil $45 \mathrm{~g} / \mathrm{kg}$, imidacloprid \\
\hline 3 & $\begin{array}{l}\mathrm{N}: 50^{\circ} 4{ }^{\prime} 23^{\prime \prime}, \mathrm{E}: 22^{\circ} 30^{\prime} 25^{\prime \prime} \\
\text { Balbina / II and III }\end{array}$ & acetamiprid, metalaxyl-M 3,8\% + mancozeb $64 \%$ \\
\hline 4 & $\begin{array}{l}\text { N:4947'39”, E:22²0’2” } \\
\text { Atol i Irys / IV and V } \\
\end{array}$ & deltamethrin, metalaxyl-M + mancozeb, acetamiprid \\
\hline 5 & $\begin{array}{c}\mathrm{N}: 49^{\circ} 37^{\prime} 44^{\prime \prime}, \mathrm{E}: 22^{\circ} 5^{\prime} 46^{\prime \prime} \\
\text { n. d. / III }\end{array}$ & deltamethrin \\
\hline 6 & $\begin{array}{c}\mathrm{N}: 49^{\circ} 99^{\prime} 52^{\prime \prime}, \mathrm{E}: 21^{\circ} 75^{\prime} 42^{\prime \prime} \\
\text { Atol / III }\end{array}$ & metaflumizone \\
\hline 7 & $\begin{array}{c}\mathrm{N}: 49^{\circ} 533^{\prime} 26^{\prime \prime}, \mathrm{E}: 22^{\circ} 47^{\prime} 00^{\prime \prime} \\
\text { Inova / III a }\end{array}$ & $\begin{array}{c}\text { glyphosate, potassium mineral fertilizer } 60 \% \mathrm{~K} \text {, ammonium phosphate, } \\
\text { nitrogen mineral fertilizer } 27 \% \mathrm{~N} \text {, linuron + clomazone, rimsulfuron, } \\
\text { propamocarb hydrochloride }+ \text { fenamidone, multi-component foliar fertilizer } \\
(\mathrm{N}, \mathrm{MgO}, \mathrm{B}, \mathrm{Cu}, \mathrm{Fe}, \mathrm{Mn}, \mathrm{Mo}, \mathrm{Zn}) \text {, tiaclopryd + deltamethrin, } \\
\text { mandipropamid }\end{array}$ \\
\hline 8 & $\begin{array}{l}\text { N:505'5”, E:22²1'33” } \\
\text { Żagiel, Denar / III }\end{array}$ & $\begin{array}{l}\text { foliar fertilizer (N, P, K, S), linuron, quizalofop-P-ethyl, thiamethoxam, } \\
\text { mancozeb + cymoxanil, metalaxyl-M + mancozeb }\end{array}$ \\
\hline 9 & $\begin{array}{l}\mathrm{N}: 49^{\circ} 53^{\prime} 33^{\prime \prime}, \mathrm{E}: 22^{\circ} 45^{\prime} 4^{\prime \prime} \\
\text { Tajfun / n. d. }\end{array}$ & $\begin{array}{c}\text { metribuzin, quizalofop-P-ethyl, metalaxyl-M + mancozeb, propamocarb } \\
\text { hydrochloride + fenamidone, mandipropamid }\end{array}$ \\
\hline 10 & $\begin{array}{l}\text { N:49³7’21”, E:226’3” } \\
\text { Jelly N /III }\end{array}$ & multi-component fertilizer $(\mathrm{N}, \mathrm{P}, \mathrm{K}, \mathrm{Mg}, \mathrm{B}, \mathrm{Fe}, \mathrm{Mn}, \mathrm{Zn})$, nitrogen fertilizer \\
\hline 11 & $\begin{array}{l}\mathrm{N}: 49^{\circ} 24^{\prime} 8^{\prime \prime}, \mathrm{E}: 22^{\circ} 35^{\prime} 9^{\prime \prime} \\
\text { n. d. / IV and V }\end{array}$ & MCPA, deltamethrin \\
\hline 12 & $\begin{array}{l}\text { N:4953'15”, E:22 } 44^{\prime} 10^{\prime \prime} \\
\text { Denar / II and III }\end{array}$ & $\begin{array}{c}\text { ammonium sulphate } 32 \% \mathrm{~N} \text {, foliar fertilizer }(\mathrm{N}, \mathrm{P}, \mathrm{Mg}, \mathrm{K}, \mathrm{S}) \text {, metribuzin, } \\
\text { propamocarb + fenamidone, propamocarb hydrochloride + fluopicolide, } \\
\text { thiacloprid + deltametrina }\end{array}$ \\
\hline 13 & $\begin{array}{l}\mathrm{N}: 49^{\circ} 59^{\prime} 43^{\prime \prime}, \mathrm{E}: 21^{\circ} 45^{\prime} 15^{\prime \prime} \\
\text { Atol / III }\end{array}$ & metaflumizone \\
\hline
\end{tabular}

*- the names of active substances are given; n.d.- no data 


\section{Catching of ground beetles}

At each site, two Barber pitfall traps were set up at a distance of $2 \mathrm{~m}$ from each other. The pitfall traps were made of plastic containers placed flush with the ground level and filled with preserving fluid ( $25 \%$ ethylene glycol solution) to $1 / 3$ of their volume. At individual sites, the traps were emptied every 2 weeks throughout the entire growing season of potato (starting from the last 10 days of April and ending in the first 10 days of September).

\section{Nomenclature and Statistical Analyses}

Identification of ground beetles was made using a study by Hurka (1996). The systematics of Carabidae followed a publication by Stachowiak (2008). The dominance structure (D) was described adopting the following classes: eudominants D5 (>10\% of individuals of an assemblage), dominants D4 (5.1-10\%), subdominants D3 (2.1-5\%), recedents D2 (1.1-2\%), and subrecedents D1 (<1\%) (Trojan, 1980). The diversity indices used to analyze beetle assemblages were as follows: Margalef's species richness diversity index (d) (Trojan, 1998), Simpson's dominance index $(\lambda)$, Shannon's species diversity index $\left(\mathrm{H}^{\prime} \mathrm{n}\right)$, and also Pielou's evenness index $\left(\mathrm{J}^{\prime}\right)$ (Magurran, 2004). The ecological and zoogeographical characteristics of carabids were described based on a study by Huruk and Barševskis (2014).

To determine similarities between the assemblages of beetles captured at individual sites, cluster analysis applying the Ward agglomeration method was used, in which the Euclidean distance was accepted as a measure of similarity. The obtained results were statistically analyzed using Statistica v.12 and Excel 2016 software.

\section{Results}

During the study conducted, a total of 7406 beetles were caught, representing 29 genera and classified in 54 species. The number of individuals and species caught as well as the indicators describing biodiversity at individual sites are collected in Table 3, whereas the dominance structure (D) of ground beetles at individual sites is shown in Table 4. The total numbers (N) and overall dominance (D) as well as the ecological and zoogeographical characteristics of species caught are presented in Table 5.

Table 3. Number of individuals and species as well as indices describing the biodiversity of Carabidae caught at individual sites

\begin{tabular}{|c|c|c|c|c|c|c|c|c|c|c|c|c|c|}
\hline & \multicolumn{13}{|c|}{ Site } \\
\hline & 1 & 2 & 3 & 4 & 5 & 6 & 7 & 8 & 9 & 10 & 11 & 12 & 13 \\
\hline Year & 2008 & 2008 & 2008 & 2011 & 2012 & 2012 & 2013 & 2013 & 2013 & 2013 & 2013 & 2013 & 2013 \\
\hline $\begin{array}{l}\text { Number of } \\
\text { species }\end{array}$ & 15 & 18 & 15 & 16 & 13 & 14 & 12 & 14 & 11 & 13 & 14 & 21 & 18 \\
\hline $\begin{array}{l}\text { Number of } \\
\text { specimens }\end{array}$ & 836 & 692 & 59 & 688 & 517 & 309 & 545 & 734 & 254 & 396 & 684 & 1272 & 420 \\
\hline $\begin{array}{l}\text { Margalef index } \\
\text { (d) }\end{array}$ & 4.79 & 5.99 & 7.91 & 5.29 & 4.42 & 5.22 & 4.02 & 4.54 & 4.16 & 4.62 & 4.59 & 6,44 & 6.48 \\
\hline $\begin{array}{c}\text { Simpson index } \\
(\lambda)\end{array}$ & 0.58 & 0.15 & 0.12 & 0.41 & 0.38 & 0.25 & 0.55 & 0.32 & 0.50 & 0.29 & 0.28 & 0.47 & 0.25 \\
\hline $\begin{array}{c}\text { Shannon index } \\
\left(H^{\prime} l_{n}\right)\end{array}$ & 1.03 & 2.19 & 2.37 & 1.26 & 1.26 & 1.72 & 0.94 & 1.45 & 1.12 & 1.56 & 1.66 & 1.28 & 1.75 \\
\hline Pielou index $\left(\mathrm{J}^{\prime}\right)$ & 0.38 & 0.76 & 0.88 & 0.45 & 0.49 & 0.65 & 0.38 & 0.55 & 0.47 & 0.61 & 0.63 & 0.42 & 0.61 \\
\hline Total & \multicolumn{2}{|c|}{$\begin{array}{c}\text { Number of } \\
\text { species } \\
54\end{array}$} & \multicolumn{2}{|c|}{$\begin{array}{c}\text { Number } \\
\text { of specimens } \\
7406\end{array}$} & \multicolumn{2}{|c|}{$\begin{array}{c}\text { Margalef } \\
\text { index (d) } \\
13.7\end{array}$} & \multicolumn{2}{|c|}{$\begin{array}{c}\text { Simpson } \\
\text { index }(\lambda) \\
0.24\end{array}$} & \multicolumn{3}{|c|}{$\begin{array}{c}\text { Shannon } \\
\text { index }\left(\mathrm{H}^{\prime} \mathrm{l}_{\mathrm{n}}\right) \\
1.94\end{array}$} & \multicolumn{2}{|c|}{$\begin{array}{c}\text { Pielou } \\
\text { index }\left(\mathrm{J}^{\prime}\right) \\
0.49\end{array}$} \\
\hline
\end{tabular}


Table 4. Results of analysing of dominance stucture of Carabidae caught at individual sites

\begin{tabular}{|c|c|c|c|c|c|}
\hline \multirow{2}{*}{ Site } & \multicolumn{5}{|c|}{ Class of dominance [D] } \\
\hline & D5 & D4 & D3 & D2 & D1 \\
\hline 1 & P.cup & H.ruf & $\begin{array}{c}\text { P.ver, P.lep, C.err, } \\
\text { A.sig }\end{array}$ & B.qua & $\begin{array}{c}\text { C. fus, A. sex, A. bin, N. bre, } \\
\text { M. lam, M. pro, A. par, D. } \\
\text { hal }\end{array}$ \\
\hline 2 & $\begin{array}{l}\text { P.mel, H.ruf, } \\
\text { M.lam, C.fus }\end{array}$ & P.cup, M.pro & - & $\begin{array}{l}\text { A.sig, C.gra, } \\
\text { T.qud, C.fos }\end{array}$ & $\begin{array}{l}\text { C. err, A. mue, A. ple, C. } \\
\text { can, P. nig, A. dor, A. flav }\end{array}$ \\
\hline 3 & $\begin{array}{l}\text { M.lam, B.qua, } \\
\text { P.mel, H.ruf, } \\
\text { C.amb } \\
\end{array}$ & $\begin{array}{l}\text { B.cep, C.fos, } \\
\text { D.hal }\end{array}$ & D.glo, M.lam & $\begin{array}{c}\text { A.bin, H.gri, P.cup, } \\
\text { P.ver, P.vrn }\end{array}$ & - \\
\hline 4 & H.ruf, P.mel & P.ver & P.nig & A.aul & $\begin{array}{c}\text { C. gra, C. fus, C. cor, N. } \\
\text { bre, A. sch, S. viv, C. ulr, C. } \\
\text { lin, C. con, C. vio, C. car }\end{array}$ \\
\hline 5 & H.ruf, P.cup & - & P.mel, P.nig, C.fus & C. vio & $\begin{array}{l}\text { N. bre, P. ver, C. nit, C. gra, } \\
\text { C. can, H. aff, P. ovo }\end{array}$ \\
\hline 6 & H.ruf, P.cup & $\begin{array}{l}\text { P.mel, C.gra, } \\
\text { D.hal, C.fus }\end{array}$ & - & C.can & $\begin{array}{l}\text { A. sig, N. bre, P. nig, C. ulr, } \\
\text { C. viol, A. bin, A. mue }\end{array}$ \\
\hline 7 & H.ruf, P.mel & - & $\begin{array}{l}\text { C.ulr, D.hal, } \\
\text { C.nit }\end{array}$ & - & $\begin{array}{l}\text { C. ger, C. cor, P. ver, A. } \\
\text { par, P. nig, S. viv, A. aul }\end{array}$ \\
\hline 8 & $\begin{array}{l}\text { P.mel, H.ruf, } \\
\text { P.cup }\end{array}$ & - & C.gra & C.fus, A.sig & $\begin{array}{c}\text { P. nig, D. hal, H. aff, P. vrn, } \\
\text { A. mue, C. can, C. nit, S. } \\
\text { pum }\end{array}$ \\
\hline 9 & H.ruf, P.mel & D.hal & P.cup, P.nig & C.fus & $\begin{array}{c}\text { B. qua, C. can, A. sig, } \\
\text { H. aff, A. dor }\end{array}$ \\
\hline 10 & $\begin{array}{l}\text { P.cup, H.ruf, } \\
\quad \text { P.mel }\end{array}$ & C.fus & P.ver, B.qua & C.vio & $\begin{array}{l}\text { N. bre, P. atr, C. cor, } \\
\text { D. hal, M. lam, P. ant }\end{array}$ \\
\hline 11 & $\begin{array}{l}\text { P.cup, C.can, } \\
\text { P.mel }\end{array}$ & H.ruf, P.ver & - & $\begin{array}{l}\text { A.sex, P.ver, } \\
\text { A.mue, C.nit }\end{array}$ & $\begin{array}{l}\text { A. bin, C. cor, L. ass, } \\
\quad \text { C. gra, P. ant }\end{array}$ \\
\hline 12 & H.ruf, P.mel & D.hal, P.cup & - & C.can, C.ulr & $\begin{array}{l}\text { C. fus, C. gra, C. arc, A. sex, } \\
\text { C. ger, B. cep, A. sig, P. obl, } \\
\text { A. mue, C. nit, C. lin, P. nig, } \\
\text { A. par, H. aff, H. lat } \\
\end{array}$ \\
\hline 13 & $\begin{array}{l}\text { H.ruf, P.cup, } \\
\quad \text { C.fus }\end{array}$ & P.mel, D.hal & А.тие & A.sig, C.gra & $\begin{array}{l}\text { C. can, B. qua, C. hyb, C. } \\
\text { fos, C. col, M. lam, P. ver, } \\
\text { A. dor, A. ple, Z. ten }\end{array}$ \\
\hline
\end{tabular}

S - study site; Name of species: N. bre-Nebria brevicollis, C. hyb-Cicindela hybrida, C. ger-Cylindera germanica, C. gra-Carabus granulatus, C. arc-Carabus arcensis, C. ulr-Carabus ulrichii, C. conCarabus convexus, C. can- Carabus cancellatus, C. lin- Carabus linnei, C. vio- Carabus violaceus, C. cor-Carabus coriaceus, C. car-Cychrus caraboides, C. fos-Clivinia fossor, C. col- Clivinia collaris, D. glo- Dyschirus globosus, B. cep-Broscus cephalotes, T. qud-Trechus qudristriatus, A. fla-Asaphidion flavipes, M. lam-Metallina lampros, M. pro-Metallina properans, B. qua-Bembidion quadrimaculatum, P. atr- Patrobus atrorufus, A. bin-Anisodactylus binotatus, A. sig-Anisodactylus signatus, H. rufHarpalus rufipes, H. gri- Harpalus griseus, H. aff- Harpalus affinis, H. lat- Harpalus latus, A. parAcupalpus parvulus, P. lep-Poecilus lepidus, P. cup-Poecilus cupreus, P. ver-Poecilus versicolor, $P$. vrn-Pterostichus vernalis, P. obl- Pterostichus oblongopuctatus, P. nig-Pterostichus niger, P. melPterostichus melanarius, P.ant-Pterostichus anthracinus, P. ovo-Pterostichus ovoideus, A. par- Abax parallelus, A. sch- Abax schueppeli rendschmidtii, S. pum-Stomis pumicatus, C. fus- Calathus fuscipes, C. err-Calathus erratus, C. amb-Calathus ambiguus, D. hal-Dolichus halensis, S. viv-Synuchus vivalis, A. mue- Agonum muelleri, A. sex-Agonum sexpunctatum, L. ass- Limodromus assimilis, A. dorAnchomenus dorsalis, A. ple-Amara plebeja, A. aul-Amara aulica, C. nit-Chlaeniellus nitidulus, Z. tenZabrus tenebrioides.

D [\%] - Dominance: D5 - eudominants, D4 - dominants, D3 - subdominants, D2 - recedents, D1 subrecedents 


$$
\text { - } 2114 \text { - }
$$

Table 5. Total number of individuals and species, overall dominance (D), and ecological characteristics of Carabdae caught at all sites

\begin{tabular}{|c|c|c|c|c|c|c|c|c|}
\hline Species & $\mathbf{N}$ & \multicolumn{2}{|c|}{ D [\%] } & I & II & III & IV & $\mathbf{V}$ \\
\hline Nebria brevicollis (F.) & 13 & 0.18 & D1 & $\mathrm{F}$ & $\mathrm{Sz}$ & $\mathrm{H}$ & $\mathrm{A}$ & EM \\
\hline Cicindela hybrida $\mathrm{L}$. & 1 & 0.01 & D1 & $\mathrm{Oa}$ & $\mathrm{Lz}$ & $X$ & $\mathrm{~S}$ & Esyb \\
\hline Cylindera germanica (L.) & 8 & 0.11 & D1 & $\mathrm{Oa}$ & $\mathrm{Lz}$ & $\mathrm{H}$ & $\mathrm{S}$ & $\mathrm{P}$ \\
\hline Carabus granulatus L. & 74 & 1.00 & D1 & $\mathrm{OaF}$ & $\mathrm{Lz}$ & $\mathrm{H}$ & $\mathrm{S}$ & Esyb \\
\hline Carabus arcensis HERBST & 7 & 0.09 & D1 & $\mathrm{F}$ & $\mathrm{Lz}$ & $\mathrm{H}$ & $\mathrm{S}$ & $\mathrm{P}$ \\
\hline Carabus ulrichii GERMAR & 31 & 0.42 & D1 & $\mathrm{Oa}$ & $\mathrm{Lz}$ & $\mathrm{Mh}$ & A & $\mathrm{E}$ \\
\hline Carabus convexus $\mathrm{F}$. & 1 & 0.01 & D1 & $\mathrm{OaF}$ & $\mathrm{Lz}$ & $\mathrm{Mh}$ & $\mathrm{S}$ & Esyb \\
\hline Carabus cancellatus ILL. & 176 & 2.38 & D3 & $\mathrm{Oa}$ & $\mathrm{Lz}$ & $\mathrm{Mh}$ & $\mathrm{S}$ & Esyb \\
\hline Carabus linnei (PANZ.) & 4 & 0.05 & D1 & $\mathrm{R}$ & $\mathrm{Lz}$ & $\mathrm{H}$ & A & GEpl \\
\hline Carabus violaceus (L.) & 14 & 0.19 & D1 & $\mathrm{F}$ & $\mathrm{Lz}$ & $\mathrm{Mh}$ & $\mathrm{S}$ & $\mathrm{P}$ \\
\hline Carabus coriaceus L. & 12 & 0.16 & D1 & $\mathrm{F}$ & $\mathrm{Lz}$ & Mh & A & $\mathrm{E}$ \\
\hline Cychrus caraboides L. & 1 & 0.01 & D1 & $\mathrm{F}$ & $\mathrm{Lz}$ & $\mathrm{H}$ & $\mathrm{S}$ & $\mathrm{Ea}$ \\
\hline Clivinia fossor (L.) & 12 & 0.16 & D1 & $\mathrm{Oa}$ & $\mathrm{Sz}$ & $\mathrm{H}$ & $\mathrm{S}$ & $\mathrm{H}$ \\
\hline Clivinia collaris (HERBST) & 1 & 0.01 & D1 & $\mathrm{Oa}$ & $\mathrm{Sz}$ & $\mathrm{H}$ & $\mathrm{S}$ & $\mathrm{P}$ \\
\hline Dyschirus globosus (HERBST) & 2 & 0.03 & D1 & $\mathrm{OaF}$ & $\mathrm{Sz}$ & $\mathrm{H}$ & $\mathrm{S}$ & $\mathrm{P}$ \\
\hline Broscus cephalotes (L.) & 7 & 0.09 & D1 & Syn & $\mathrm{Sz}$ & $\mathrm{Mh}$ & A & Esyb \\
\hline Trechus qudristriatus (SCHRANK) & 10 & 0.14 & D1 & $\mathrm{Oa}$ & $\mathrm{Sz}$ & $\mathrm{Mh}$ & $\mathrm{S}$ & $\mathrm{P}$ \\
\hline Asaphidion flavipes (L.) & 1 & 0.01 & D1 & $\mathrm{Oa}$ & $\mathrm{Sz}$ & $\mathrm{Mh}$ & $\mathrm{S}$ & $\mathrm{P}$ \\
\hline Metallina lampros (HERBST) & 85 & 1.15 & D2 & $\mathrm{Oa}$ & $\mathrm{Sz}$ & $\mathrm{Mh}$ & $\mathrm{S}$ & $\mathrm{P}$ \\
\hline Metallina properans (HERBST) & 70 & 0.95 & D1 & $\mathrm{Oa}$ & $\mathrm{Sz}$ & $\mathrm{H}$ & $\mathrm{S}$ & $\mathrm{P}$ \\
\hline Bembidion quadrimaculatum (L.) & 73 & 0.99 & D1 & $\mathrm{Oa}$ & $\mathrm{Sz}$ & $\mathrm{Mh}$ & A & $\mathrm{H}$ \\
\hline Patrobus atrorufus (STROM.) & 3 & 0.04 & D1 & $\mathrm{OaF}$ & $\mathrm{Sz}$ & $\mathrm{H}$ & A & Esyb \\
\hline Anisodactylus binotatus (F.) & 9 & 0.12 & D1 & $\mathrm{Oa}$ & $\mathrm{Sz}$ & $\mathrm{H}$ & $\mathrm{S}$ & $\mathrm{P}$ \\
\hline Anisodactylus signatus (PANZ.) & 55 & 0.74 & D1 & $\mathrm{F}$ & $\mathrm{Sz}$ & $\mathrm{Mh}$ & $\mathrm{S}$ & EM \\
\hline Harpalus rufipes (DE GEER) & 2943 & 39.74 & D5 & $\mathrm{Oa}$ & $\mathrm{Hz}$ & $\mathrm{Mh}$ & A & $\mathrm{P}$ \\
\hline Harpalus griseus (PANZ.) & 1 & 0.01 & D1 & $\mathrm{Oa}$ & $\mathrm{Hz}$ & $X$ & A & $\mathrm{P}$ \\
\hline Harpalus affinis (SCHRANK) & 9 & 0.12 & D1 & $\mathrm{Oa}$ & $\mathrm{Hz}$ & $\mathrm{X}$ & $\mathrm{S}$ & $P$ \\
\hline Harpalus latus (L.) & 1 & 0.01 & D1 & $\mathrm{Oa}$ & $\mathrm{Hz}$ & $\mathrm{Mh}$ & A & $\mathrm{P}$ \\
\hline Acupalpus parvulus (STURM) & 1 & 0.01 & D1 & $\mathrm{Oa}$ & $\mathrm{Sz}$ & $\mathrm{H}$ & A & $\mathrm{P}$ \\
\hline Poecilus lepidus (LESKE) & 37 & 0.50 & D1 & $\mathrm{Oa}$ & $\mathrm{Sz}$ & $\mathrm{Mh}$ & A & Esyb \\
\hline Poecilus cupreus (L.) & 1742 & 23.52 & D5 & $\mathrm{OaF}$ & $\mathrm{Sz}$ & $\mathrm{Mh}$ & $\mathrm{S}$ & $\mathrm{P}$ \\
\hline Poecilus versicolor (STURM) & 111 & 1.50 & D2 & $\mathrm{Oa}$ & $\mathrm{Sz}$ & $\mathrm{Mh}$ & $\mathrm{S}$ & Esyb \\
\hline Pterostichus vernalis (PANZ.) & 52 & 0.70 & D1 & $\mathrm{R}$ & $\mathrm{Sz}$ & $\mathrm{H}$ & $\mathrm{S}$ & $\mathrm{P}$ \\
\hline Pterostichus oblongopuctatus (F.) & 3 & 0.04 & D1 & $\mathrm{F}$ & $\mathrm{Sz}$ & $\mathrm{Mh}$ & $\mathrm{S}$ & $\mathrm{P}$ \\
\hline Pterostichus niger (SCHALL.) & 61 & 0.82 & D1 & $\mathrm{F}$ & $\mathrm{Lz}$ & $\mathrm{Mh}$ & $\mathrm{S}$ & Esyb \\
\hline Pterostichus melanarius (ILL.) & 1211 & 16.35 & D5 & $\mathrm{Oa}$ & $\mathrm{Lz}$ & $\mathrm{Mh}$ & A & Esyb \\
\hline Pterostichus anthracinus (ILL.) & 2 & 0.03 & D1 & $\mathrm{R}$ & $\mathrm{Sz}$ & $\mathrm{H}$ & $\mathrm{S}$ & $\mathrm{P}$ \\
\hline Pterostichus ovoideus (STURM) & 1 & 0.01 & D1 & $\mathrm{R}$ & $\mathrm{Sz}$ & $\mathrm{H}$ & A & $\mathrm{P}$ \\
\hline Abax parallelus (DUFT.) & 6 & 0.08 & D1 & $\mathrm{F}$ & $\mathrm{Sz}$ & $\mathrm{Mh}$ & $\mathrm{S}$ & $\mathrm{E}$ \\
\hline Abax schueppeli rendschmidtii (GERM.) & 3 & 0.04 & D1 & $\mathrm{F}$ & $\mathrm{Sz}$ & $\mathrm{Mh}$ & $\mathrm{S}$ & GEpl \\
\hline Stomis pumicatus (PANZ.) & 1 & 0.01 & D1 & $\mathrm{OaF}$ & $\mathrm{Sz}$ & $\mathrm{H}$ & $\mathrm{S}$ & EM \\
\hline Calathus fuscipes GOEZE & 220 & 2.97 & D3 & $\mathrm{OaF}$ & $\mathrm{Sz}$ & $\mathrm{Mh}$ & A & $\mathrm{P}$ \\
\hline Calathus erratus (C.R. SAHLB.) & 34 & 0.46 & D1 & $\mathrm{OaF}$ & $\mathrm{Sz}$ & $\mathrm{Mh}$ & A & $\mathrm{P}$ \\
\hline Calathus ambiguus (PAYK.) & 6 & 0.08 & D1 & $\mathrm{Oa}$ & $\mathrm{Sz}$ & $\mathrm{Mh}$ & A & $\mathrm{P}$ \\
\hline Dolichus halensis (SCHALL.) & 177 & 2.39 & D3 & $\mathrm{Oa}$ & $\mathrm{Sz}$ & $\mathrm{Mh}$ & $\mathrm{S}$ & $\mathrm{P}$ \\
\hline Synuchus vivalis (ILL.) & 4 & 0.05 & D1 & $\mathrm{OaF}$ & $\mathrm{Sz}$ & $\mathrm{Mh}$ & A & Esyb \\
\hline Agonum muelleri (HERBST) & 39 & 0.53 & D1 & $\mathrm{OaF}$ & $\mathrm{Sz}$ & $\mathrm{Mh}$ & $\mathrm{S}$ & $\mathrm{H}$ \\
\hline Agonum sexpunctatum (L.) & 22 & 0.30 & D1 & $\mathrm{F}$ & $\mathrm{Sz}$ & $\mathrm{Mh}$ & $\mathrm{S}$ & $\mathrm{P}$ \\
\hline Limodromus assimilis (PAYK.) & 2 & 0.03 & D1 & $\mathrm{F}$ & $\mathrm{Sz}$ & $\mathrm{H}$ & $\mathrm{S}$ & $\mathrm{P}$ \\
\hline Anchomenus dorsalis (PONT.) & 4 & 0.05 & D1 & $\mathrm{OaF}$ & $\mathrm{Sz}$ & $\mathrm{Mh}$ & $\mathrm{S}$ & $\mathrm{P}$ \\
\hline Amara plebeja (GYLL.) & 6 & 0.08 & D1 & $\mathrm{Oa}$ & $\mathrm{Hz}$ & $\mathrm{Mh}$ & $\mathrm{S}$ & $\mathrm{P}$ \\
\hline Amara aulica (PANZ.) & 13 & 0.18 & D1 & $\mathrm{Oa}$ & $\mathrm{Hz}$ & $\mathrm{H}$ & $\mathrm{S}$ & $\mathrm{P}$ \\
\hline Chlaeniellus nitidulus (SCHRANK) & 23 & 0.31 & D1 & $\mathrm{R}$ & $\mathrm{Sz}$ & $\mathrm{H}$ & $\mathrm{A}$ & $\mathrm{E}$ \\
\hline Zabrus tenebrioides (GOEZE) & 1 & 0.01 & D1 & $\mathrm{Oa}$ & $\mathrm{Hz}$ & $\mathrm{Mh}$ & $\mathrm{A}$ & $\mathrm{P}$ \\
\hline
\end{tabular}

I- Habitat: F- forest, Oa- open area, OaF- open area and forest, R- riparian, Syn- synanthropic; II- Trophic categories: Lz- large zoophage, Sz- small zoophage. Hz- hemizoophage; III- Moisture preferences: Hhygrophilous, Mh- mesohygrophilous, X- xerophilous; IV- Breeding preferences: A- autumn breeder, Sspring breeder; V- Zoogeographical elements: E- European, Ea-Euro-Arctic, Esyb- Eyro-Siberian, EMEuro-Mediterranean, GEPL- European Forest Province [montane], H- Holarctic, P- Palearctic. D [\%]Dominance: D5- eudominants, D4- dominants, D3- subdominants, D2- recedents, D1- subrecedents 
In terms of total numbers, $H$. rufipes, $P$. cupreus, and $P$. melanarius were species found in greatest numbers. At individual sites, these species also occurred in large numbers, but only $H$. rufipes was recorded at all study sites. The highest number of species was found at site 12 (21 taxa). At the same time, it was the site where the highest number of individuals was recorded (1272 exx.). The lowest number of species (11) was found at site 9 , while as regards the number of individuals - at site 3 (59 exx.).

Overall, four dominance classes were distinguished, with the highest percentage of the least numerous class, i.e. subrecedents (D1) (46 species, more than $85 \%$ of the entire assemblage).

The recedent class (D2) was represented by 2 species that accounted for $3.7 \%$ of the total number. Three species $(5.6 \%)$ were classified both in the eudominant (D5) and subdominant (D3) classes. The dominant class (D4), however, was not recorded. A slightly different dominance structure was observed at individual sites. Among all study areas, all dominance classes were only found at five of them (sites 1, 4, 9, 10, and 13), but still with a distinct proportion of subrecedents. The degree of dominance reached the highest value at site $1(\lambda=0.58)$ (Fig. 2a-b, Tables 4 and 5).

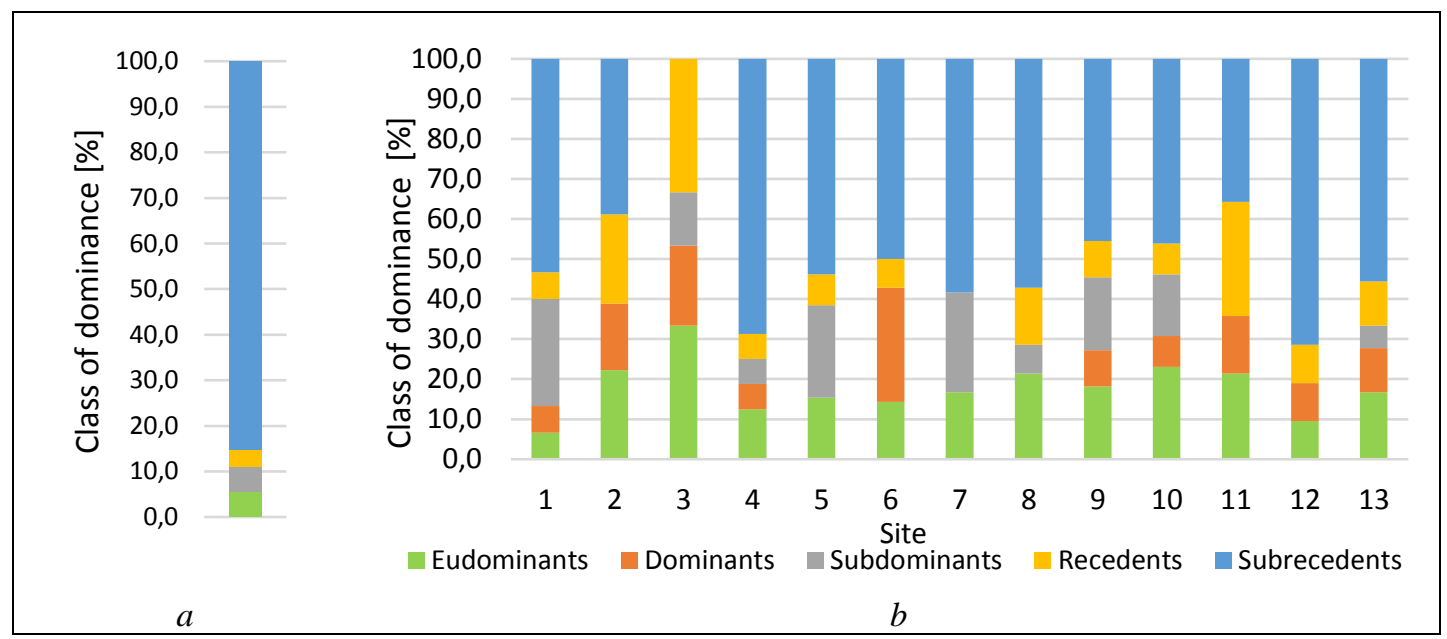

Figure 2a-b. Overall percentage of particular dominance classes of Carabidae (a) and at individual sites $(b)$

Forest, open area, open area and forest, riparian and synanthropic species were found to be present in the Carabidae assemblage. Open area species constituted the dominant group and they accounted for $46.3 \%$ of the entire assemblage, whereas their percentage at individual sites ranged $31.3-73.3 \%$. The group of forest species was second ranking and their percentage was $22.2 \%$ of the total number. At individual sites, however, it was the third ranking category with an average percentage of $19 \%$. A comparable proportion was determined for open area and forest species. Overall, they made up 20.4\%, whereas the average for the study areas was $23.5 \%$. Riparian species constituted $9.3 \%$ of the entire assemblage, while synanthropic species were least numerous. In this category, only Broscus cephalotes (L.) with a percentage of $1.9 \%$. The above-mentioned five habitat categories were only found at one site (no. 12). At the other sites, the number of distinguished categories was 3 (sites 1,2 , and 13) or 4 (sites $3,4,5,6,7,8,9,10$, and 11) (Fig. 3a-b, Table 5). 


$$
-2116-
$$

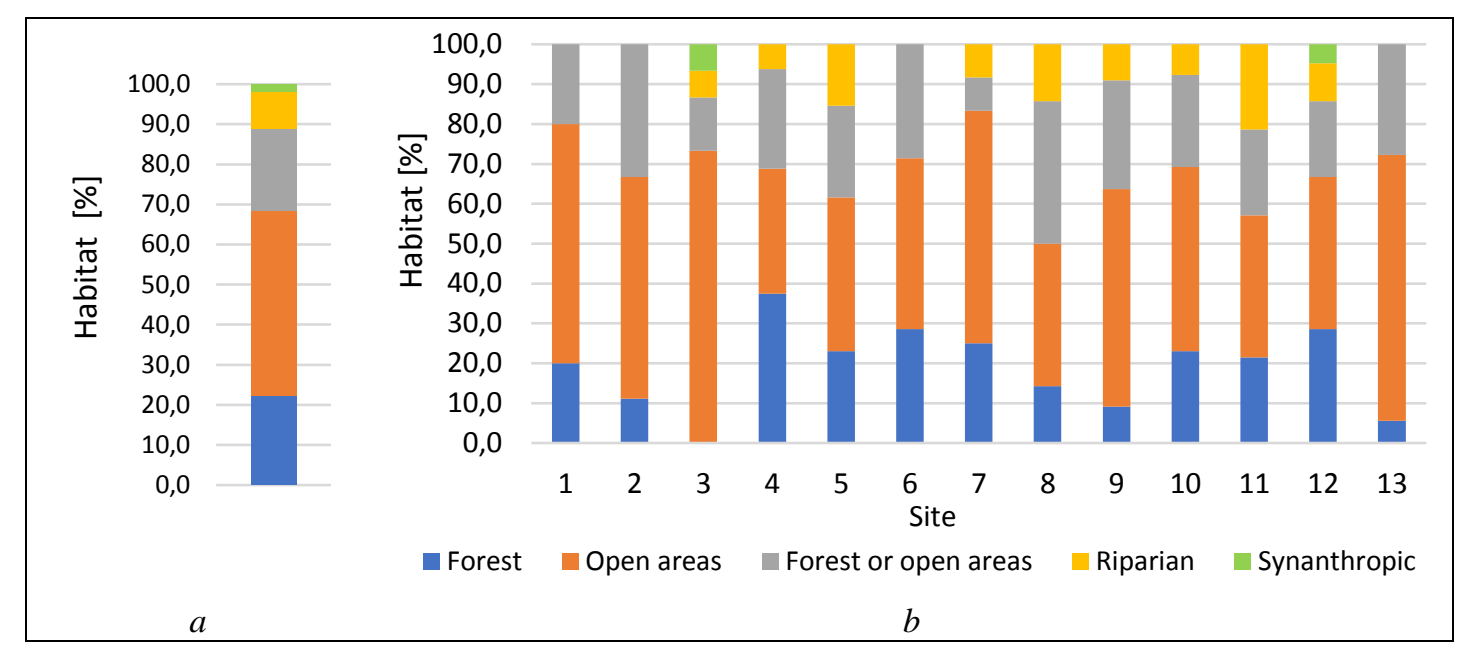

Figure 3a-b. Overall percentage of habitat categories of Carabidae (a) and at individual sites (b)

The analysis of the trophic structure showed three components to be present. Small zoophages were represented in largest numbers both in total terms and at individual sites. Overall, their percentage was $63 \%$, whereas for the study sites the average percentage of this trophic group was 55.9\%. Small zoophages were the second ranking class in terms of numbers only at two sites (4 and 9). Large zoophages, in turn, were found at 12 sites, with visible fluctuations in their numbers, similarly to the previous group. Their total percentage was $24.1 \%$. At site 1 , no species belonging to this trophic group were found. Hemizoophages were least numerous, accounting for $13 \%$ of all species. In quantitative terms, they occurred in greatest numbers at site 9 (Fig. 4a-b, Table 5).

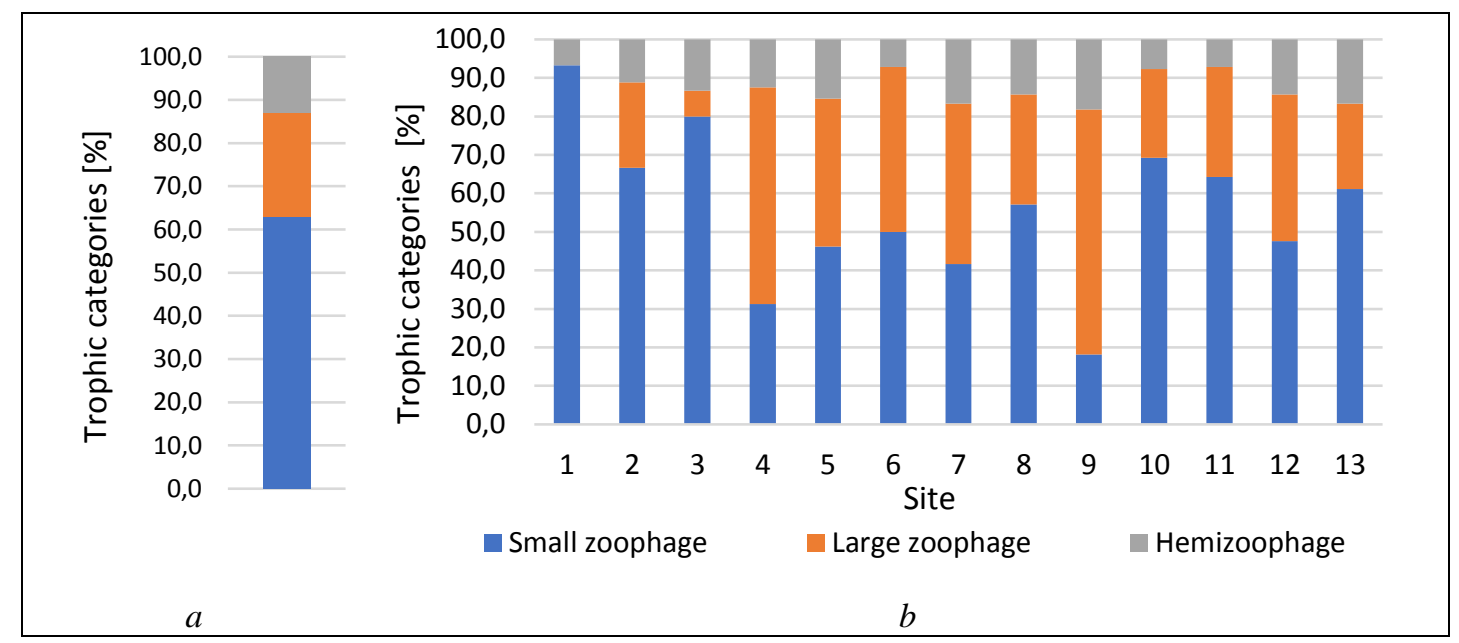

Figure 4a-b. Overall percentage of particular trophic categories of Carabidae (a) and at individual sites $(b)$

As far as moisture preferences are concerned, three types were distinguished. Species found in large numbers in habitats of diverse nature in terms of moisture, i.e. mesohygrophiles, constituted the largest group. Their percentage in the entire assemblage was $57.4 \%$. At individual sites, this percentage ranged between $57.1 \%$ (site 11) and $90.9 \%$ 
(site 9) (on average 72.2\%). Fewer hygrophilous species, that is, associated with strongly moist and wet environments, were found. They accounted for $37 \%$ of all carabids identified. At individual sites, in turn, the average percentage of this group was $24.6 \%$. They occurred in greatest numbers at site 11 where their percentage was $42.9 \%$. The only site where hygrophilous species were not observed to be present was site 9 . Xerophiles, i.e. dry-loving species preferring environments with low humidity and strong insolation, were the last and at the same time least numerous group. Overall, they accounted for $5.6 \%$ of all species found, but at individual sites their percentage contribution was lower, averaging 3.1\%. Xerophilous species were recorded at six sites $(3,5,8,9,12$, and 13); among them, site 9 was found to have the highest percentage (9.1\%) (Fig. 5a-b, Table 5).

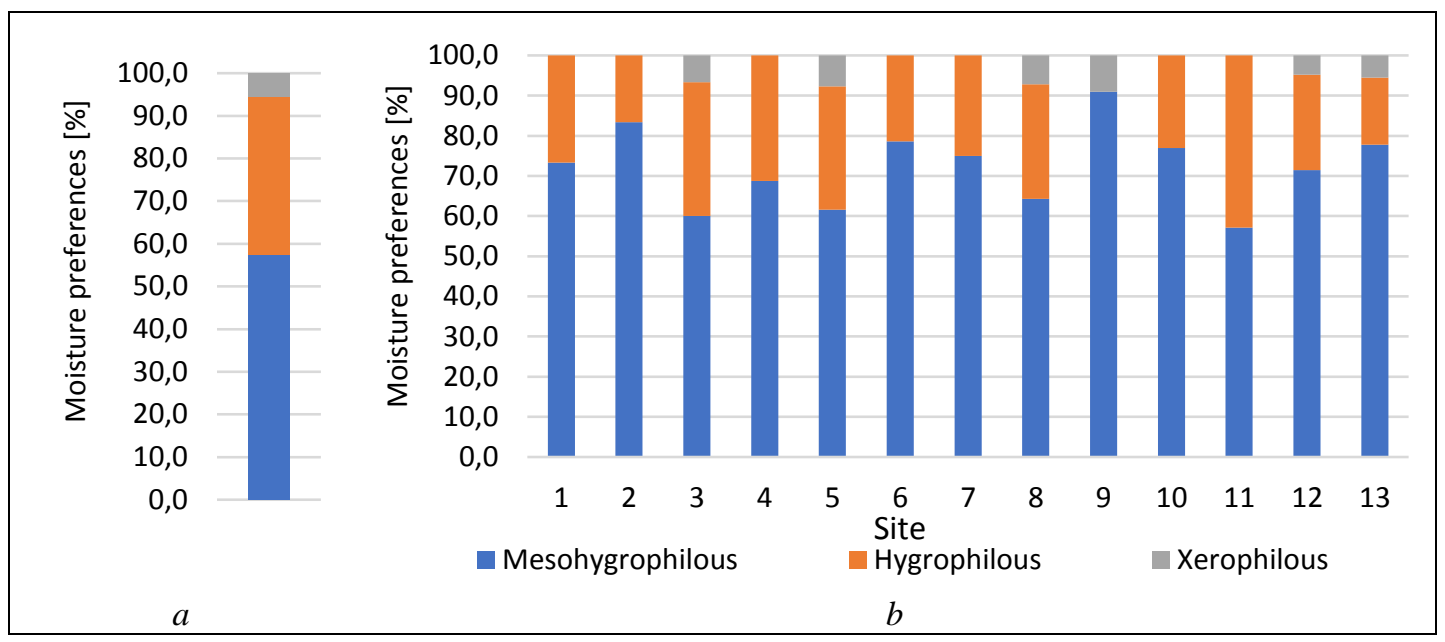

Figure 5a-b. Overall percentage of particular moisture preferences of Carabidae (a) and at individual sites $(b)$

In the assemblage of Carabidae caught, two breeding types were distinguished: species overwintering in the form of imago, i.e. spring breeders, and species being autumn breeders, that is, overwintering at the pre-imaginal stage. Spring breeding was found in $63 \%$ of ground beetles identified, while for individual sites the percentage of this category ranged from $46.2 \%$ to $72.2 \%$, with an average value of $60.8 \%$. The proportion of autumn breeders was lower, with their overall percentage standing at $37 \%$. The lowest percentage of autumn breeding species was recorded at two sites: 2 and 13 (27.8\% at either of them). Site 10, on the other hand, was observed to have the highest percentage of this ecological category, which was $53.8 \%$ of individuals collected at this site (Fig. 6a-b, Table 5).

The carabid fauna comprised seven zoogeographical elements. Overall, Palearctic species were most numerous, accounting for 55.6\% of species found. Euro-Siberian species had a lower percentage: $20.4 \%$. The other elements were represented by a much lower number of species: European (7.4\%), Holarctic and Mediterranean (5.6\%), montane European Forest Province (3.7\%), and Euro-Arctic (1.9\%). Palearctic and EuroSiberian species were found at all sites. Cychrus caraboides L., as the only representative of the Euro-Arctic element, was only found at site 4 (1.9\% of all species) (Fig. 7c). At the same time, this site and site 12 were shown to exhibit the greatest variation in ground beetles in terms of range (6 elements). Sites 3 and 7 were least chorologically varied as only 3 elements of this ecological category were recorded there (Fig. 8a-b, Table 5). 


$$
\text { - } 2118 \text { - }
$$

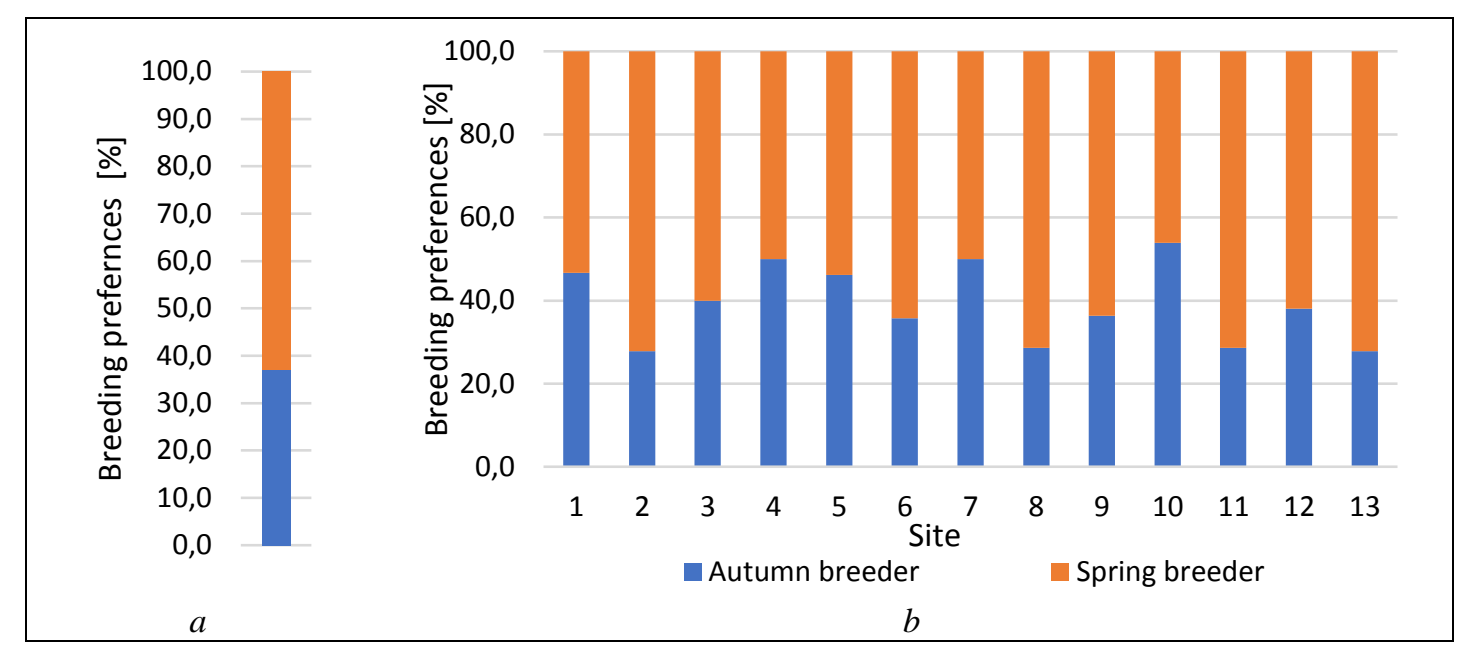

Figure 6a-b. Overall percentage of particular breeding preferences of Carabidae (a) and at individual sites $(b)$
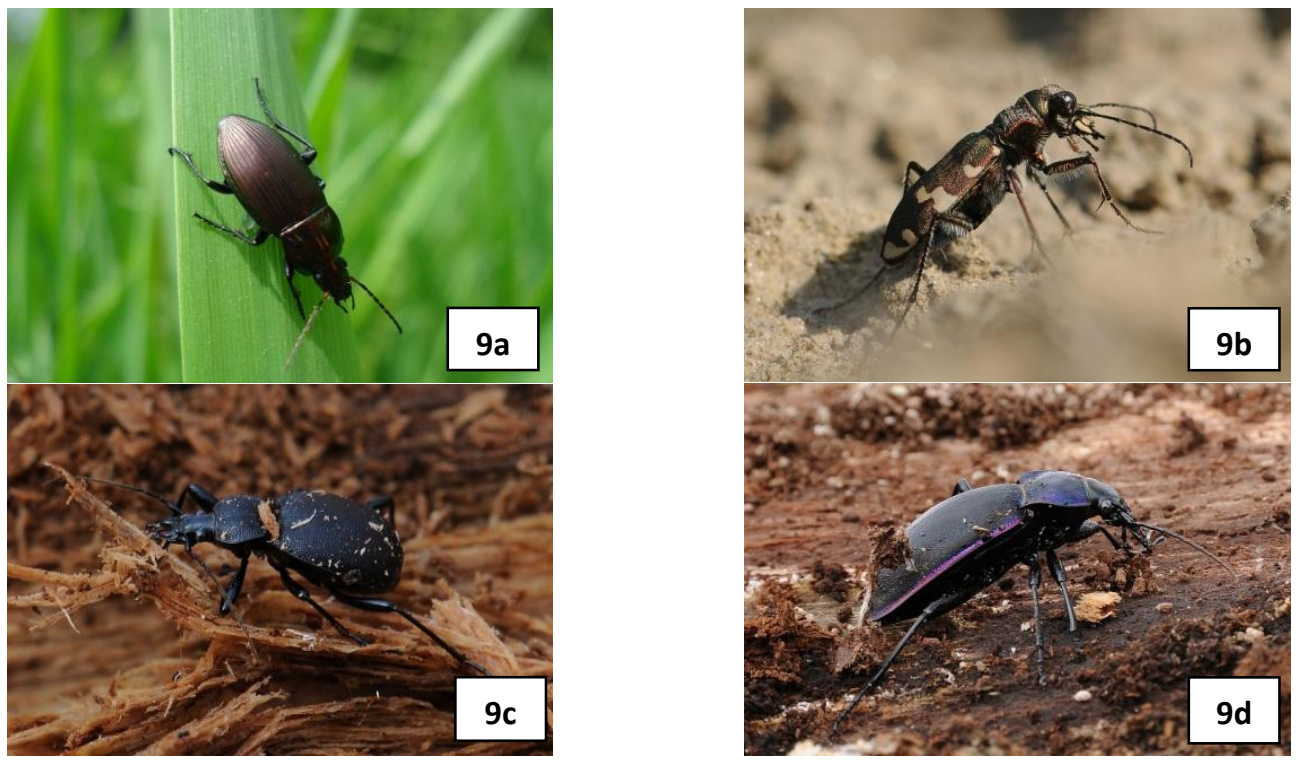

Figure 7a-d. Representatives of different ecological groups of zoophagous Carabidae caught in potato cultivations at selected sites in Subcarpathian Voivodeship: (a) Poecilus cupreus (L.) representative of the eudominant class (D5), open and wooded area species; (b) Cicindela hybrida L. - xerophile, open area species; (c) Cychrus caraboides L.- representative of the

Euro-Arctic element, forest species; (d) Carabus violaceus (L.)-representative of the subrecedent class, forest species (photo by T. Olbrycht)

In overall terms, the assemblage's diversity indices were as follows, respectively: Shannon's species diversity $\mathrm{H}_{\mathrm{ln}}^{\prime}=1.94$, while Pielou's evenness $\mathrm{J}^{\prime}=0.49$. The values of the above-mentioned indices at individual sites differed from the total value. The species diversity index $(d)$ reached the highest value at site $3(d=7.91)$, whereas the lowest one at site $7(\mathrm{~d}=4.02)$. The other biodiversity indices also had the minimum and maximum values, respectively, at the same sites: $\mathrm{H}^{\prime} \ln =2.37$ (the highest value at site 3 ), $\mathrm{H}_{\mathrm{ln}}=0.94$ 


$$
-2119 \text { - }
$$

(the lowest value at site 7), $J^{\prime}=0.88$ (the highest value at site 3 ), $J^{\prime}=0.38$ (the lowest value at sites 1 and 7). The Simpson dominance index $(\lambda)$ was 0.24 .

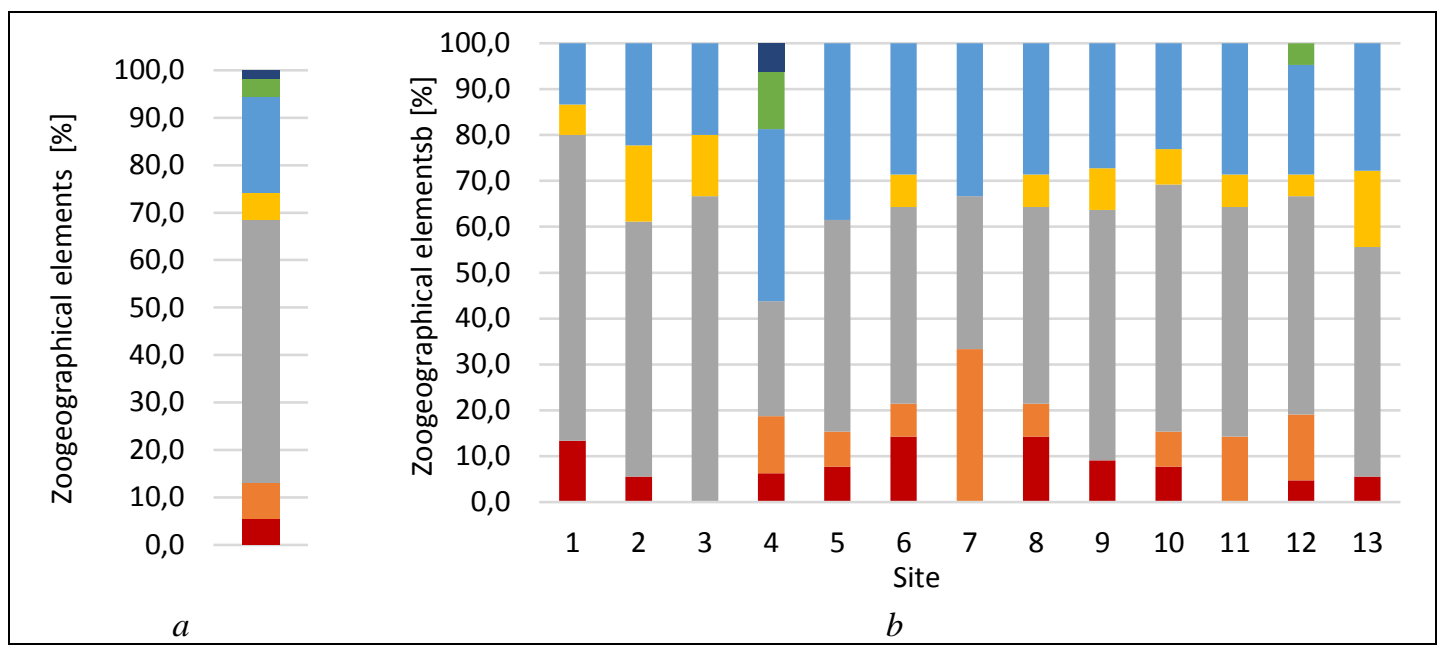

Figure 8a-b. Overall percentage of zoogeographical elements of Carabidae (a) and at individual sites $(b)$

The analysis of similarities between the Carabidae assemblages caught at individual sites revealed that sites 6 and 13 as well as sites 4 and 7 were most similar to each other in terms of beetles inhabiting them. Site 12 occupied a separate position in the dendrogram (Fig. 9).

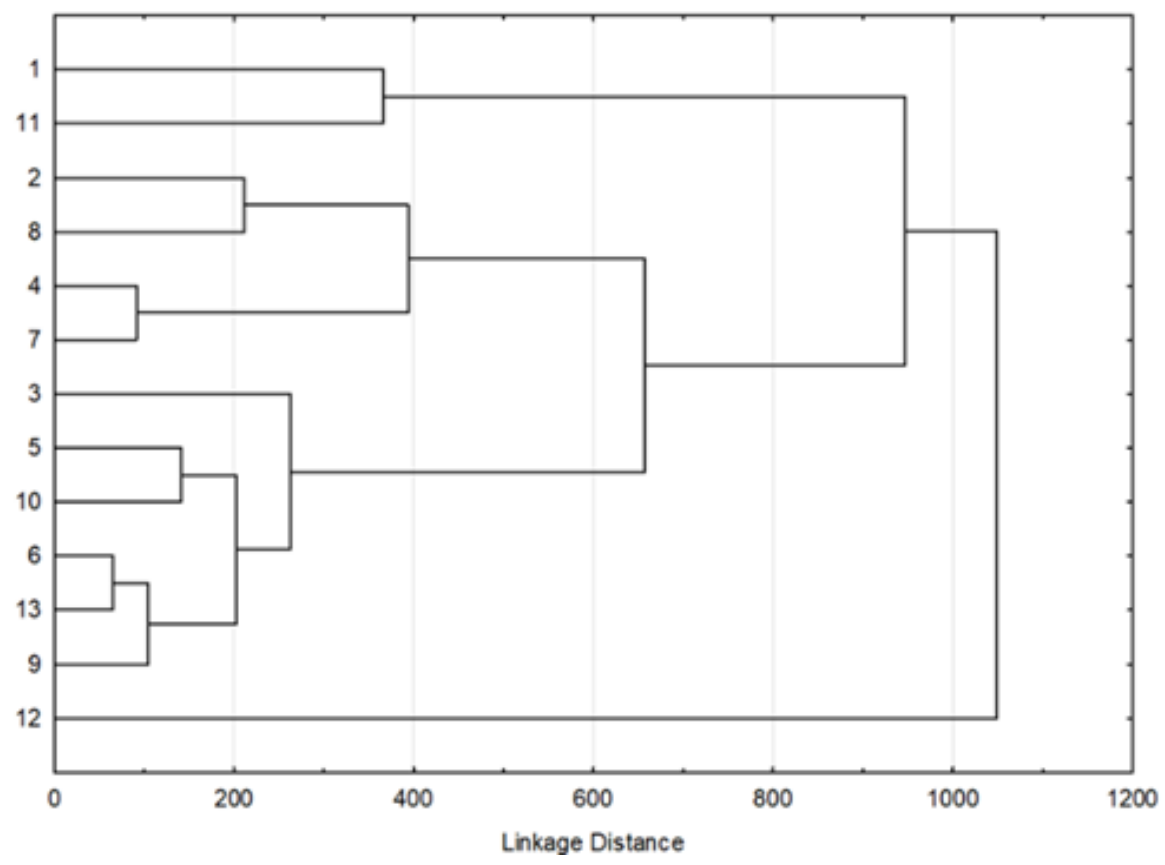

Figure 9. Dendrogram of faunistic similarity of Carabidae inhabiting potato cultivations at selected sites in Subcarpathian Voivodeship. Cluster analysis by the Ward method, the Euclidean distance as a measure of similarity 


\section{Discussion}

According to the research by Basedow et al. (1976) and Thiele (1977), in one-year studies 20-35 species are found in the qualitative structure of ground beetles of cultivation fields in Central Europe. 54 Carabidae species were recorded in the cross-sectional study of potato cultivations in the Subcarpathian region, while the average number of species per site was 15 . The highest number of species was shown at site 12 (21 species identified). The number of beetles caught is dependent not only on environmental factors (temperature, humidity, climate) and the adopted research methodology (number of traps, study period), but in the case of agricultural ecosystems also on the type of cultivations, application of cultivation protection products, soil type, and adjacent biocenoses (Thiele, 1977; Aleksandrowicz, 2002; Bale et al., 2002; Huruk, 2002, 2006; Irmler, 2003; Kosewska and Nijak, 2012; Nijak et al., 2013).

The number of Carabidae species captured in potato cultivations varies. Compared to other publications, Koval (2012) showed a very large number of ground beetle taxa - 171 species. However, it is worth noting that this study, designed to determine the adaptation of Carabidae as zoophages feeding on Leptinotarsa decemlineata, was conducted within the area of nine regions in three countries (Russia, Ukraine, and Moldova) and covered a nearly 30-year study period. Another review publication reports a much lower number of species than in the study by Koval (2012), but almost twice higher than in the case of oneor two-year observations. In Latvia Bukejs et al. (2009) revealed 59 ground beetle species. This review included studies from the period 1960-2009. On the other hand, studies conducted over a shorter period of time present different results. A four-year study on the species composition of ground beetles of potato cultivations differing in soil type which was conducted in Russia showed a total of 58 taxa, out of which the number of species identified ranged from 26 to 34 depending on the site. In turn, a two-year study carried out in Latvia revealed a total of 44 Carabidae species (34 species in the first year of the study, 38 - in the second one) (Bukejs, 2009). As far as the number of species is concerned, similar results were obtained by Juen et al. (2003) in Austria. These authors recorded 46 imaginal species and 25 species at the larval stage. In Austria research was also conducted by Kromp (1990) and Traugott (1998) and the study results were also similar in their case. Kromp (1990) demonstrated a total of 48 species, whereas Traugott (1998) - 49. A smaller number of species was reported by Nijak et al. (2013) who described 39 taxa, Nijak et al. (2014) - 34 species, Kinnunen and Tiainen (1999) - 35 species, whereas Kosewska and Nijak (2012) - 32 species. A one-year study was also done by Jasiński et al. (2015) who found 11 (the first site) and 7 (the second site) species under organic farming system.

The most frequently occurring species (D5-eudominants) in the Subcarpathian region were $H$. rufipes, $P$. cupreus, and $P$. melanarius, which are components of epigeic Carabidae fauna commonly found in cultivation fields (Thiele, 1977). H. rufipes was a species that occurred most frequently at individual sites. At most of the sites, this species constituted the eudominant class (D5) and was classified as dominant (D4) only at two sites (1 and 11). It also proved to be the most numerous in other authors' studies (Juen et al., 2003; Kosewska et al., 2008; Kosewska and Nijak, 2012; Nijak et al., 2014).

Poecilus cupreus was the second most numerous Carabidae species in this study investigating the Subcarpathian region. This species occurred at 11 sites (it was not found at sites 4 and 7). Nevertheless, the numbers of this beetle in an agricultural ecosystem vary. In the study by Bukejs (2009), it was the most numerous species (whereas H. rufipes was a subrecedent). In the research of Kosewska and Nijak (2012), it achieved the 
subdominant status in integrated farming, whereas in organic farming - the subrecedent status. Under organic potato cultivation, in turn, Jasiński et al. (2015) showed this species to be an eudominant (D5) at site I, while at site II it was not found. In the study by Kosewska et al. (2008), P. cupreus was a dominant, whereas in the study by Traugott (1998), in turn, it proved to be an eudominant.

Similarly to $P$. cupreus, $P$. melanarius was a species that occurred in very large numbers both in the Subcarpathian region and in Austria (Traugott, 1998; Juen et al., 2003). It proved to be dominant (D4) or subdominant (D3) at locations in western Poland (Kosewska and Nijak, 2012), whereas in Latvia a subrecedent (D1) (Bukejs, 2009). In the present study, this species occurred at 12 sites where it constituted the eudominant (D5) or dominant (D4) class. Its numbers were lower only at one site (no. 5) where it was classified as a subdominant (D3). But it was not found at site 1 .

A characteristic feature of the distribution of dominance of carabids inhabiting cultivation fields is the presence of a small number of dominant species with a very large proportion of individuals and a larger number of common species but represented by low numbers of individuals (Baranová et al., 2013). We see a very clear confirmation of this finding in the structure of Carabidae occurring at site no. 12. The analysis of the dendrogram (Fig. 9) revealed that this site stood out most in relation to the other study sites. In quantitative terms, the following eudominant species prevailed: H. rufipes and $P$. melanarius, which accounted for $77.9 \%$ of the assemblage (991 individuals). But in qualitative terms, this class accounted for $9.5 \%$, similarly to dominants and subdominants (either of these classes was represented by two species). The recedent class was not found, whereas subrecedents were the most numerous class $(71.4 \%$ of the assemblage, 15 species).

As reported by Czechowski (1981), agronomic practices used in cultivation fields promote the occurrence of open area species. The obtained study results confirm this dependence since nearly a half of species recorded are grouped in this ecological class (49\% of individuals). Open area and forest species (ecotone ones) as well as forest species constituted the second ranking class, in terms of numbers, accounting for $23.5 \%$ and $19 \%$, respectively. The presence of these species in the agrarian structure results from the presence of dendroflora in agricultural landscape and the migration capacity of ground beetles that seek both shelter and food in biocoenoses adjacent to cultivations (Krzysztofiak, 2001). Riparian species were less numerous (7.6\%), while synanthropic species, which were represented only by one species $-B$. cephalotes $(1.9 \%$ of the total number), were least numerous.

Trophism is another important factor used to analyze the carabidofauna structure. Both in qualitative and quantitative terms, zoophages were predominant in the entire carabid assemblage (47 species, $87 \%$ of the total number). The proportion of hemizoophages was small (7 species, $13 \%$ of the total number). However, the proportion of zoophagous species was not even as small zoophages were predominant (34 species, $63 \%$ of the total number). At site 1, no large zoophages were found at all, whereas small zoophages accounted for $93.3 \%$ of the assemblage. In turn, a high predominance of large zoophages was observed at two sites (4-56.3\%, and 9-63.6\%). The dominance of large zoophages is a very beneficial phenomenon, evidencing good condition of an environment (Szyszko, 1997). The dominance, both quantitative and qualitative, of predatory species is important from the ecological point of view because it may provide environmental resistance since zoophagous carabids reduce significantly the number of phytophagous species that threaten agricultural cultivation plantations (Koval, 1999; Aleksandrowicz, 2004). 
Nonetheless, the prevailing tendency towards a higher number of small zoophages is a typical phenomenon, characteristic of habitats that are subjected to adverse impacts of external factors; an increase in this tendency causes the numbers of hemizoophages to grow (Pałosz, 1995; Leśniak, 1997). Worth noting is also the fact that out of the total number of 13 species of large zoophages, 8 of them were beetles of the genus Carabus. It is a satisfactory result because in the research of other authors this number is usually lower. Juen et al. (2003) showed 3 species, both Bukejs (2009) and Jasiński et al. (2015) found 2 species, whereas Kinnunen and Tiainen (1999) only 1. Kosewska and Nijak (2012), in turn, did not demonstrate any species belonging to this genus. Varvara (2010) recorded a higher number of species of the genus Carabus occurring in potato cultivations. 11 species were described but this study covered a larger area (5 regions) and a longer study period (18 years).

It is also worth noting the fact that 3 species belonging to the genus Carabus caught in these studies are protected in Poland (C. ulrichii Germar, C. convexus F., and C. coriaceus Ill.). It was surprising to record two riparian species: Pterostichus ovoideus (Sturm) and Carabus linnei (Panz.). Both species were found in investigations of agrocenoses but not in potato cultivations (Konieczna et al., 2015). In a study by Szewkienicz and Olbrycht (2012), however, P. ovoideus was found in organic potato cultivation in the Subcarpathian region.

The analysis of moisture preferences showed mesohygrophilous species to have a dominant proportion (57.4\%), with a much lower percentage of hygrophilous species, strictly associated with wet biocenoses (37\%). According to Thiele (1977), the predominance of mesohygrophilous species is typical for European agroecosystems. Only 3 species, Cicindela hybrida L., Harpalus griseus (Panz.), and H. affinis (Schrank), represented dry-loving (xerophilous) species (5.56\%).

The beetles caught were also characterized in terms of their breeding preferences. In the studied material, spring breeding species were predominant (63\% of the assemblage - 34 species), whereas autumn breeding was represented by 20 species (37\% of the assemblage). Similar results were obtained by Borowski et al. (1996) who indicated this breeding preference as characteristic of Carabidae occurring at sites where cultivation protection products are used. The variation in phenology is confirmed by the difference in the catch rate of individual species since the largest numbers and fluctuations were observed in spring and summer months.

Palearctic (55.6\% of the total number) and Euro-Siberian (20.4\% of the total number) species predominated in the studied material. As reported by Czechowski (1981) and Huruk (2006), these are zoogeographical elements characteristic of cultivation fields. Wide range spectra are characteristic of species occurring in environments subjected to greater pressure of external factors. Natural or semi-natural habitats, on the other hand, favor the occurrence of species with narrower zoogeographical ranges (Leśniak, 1997; Huruk et al., 2014). C. caraboides was such a species, the only representative of the Euro-Arctic element which was only found at one site (no. 4).

Species diversity is an important indicator describing a Carabidae assemblage (Nijak et al., 2013). The total value of $\mathrm{H}_{\mathrm{ln}}^{\prime}=1.94$ and the values obtained at individual sites $\left(\mathrm{H}^{\prime}{ }_{\mathrm{ln}}\right.$ ranging 0.94-2.37) are comparable with results obtained by other authors: $\mathrm{H}^{\prime} \ln =2.108$ (Kosewska et al., 2008), $\mathrm{H}^{\prime} \ln =1.98$ and $\mathrm{H}^{\prime} \ln =2.38$ (Kosewska and Nijak, 2012), $\mathrm{H}^{\prime}{ }_{\mathrm{ln}}=2.17$ and $\mathrm{H}^{\prime}$ ln $=1.58$ (Jasiński et al., 2015). A higher value of this index characterizes assemblages with a quite good internal structure (species distribution), though not very numerous. The highest value of this indicator was observed at site 3 , which was 
characterized by the lowest number of individuals (59) and a medium number of species (15). The Pielou evenness index $\left(\mathrm{J}^{\prime}\right)$ represents the equal distribution of individuals among all species. The total value of this index in the carabid assemblage was $\mathrm{J}^{\prime}=0.49$, which could have been due to a large (dominant) proportion of rare species. In turn, at site 3 where the subrecedent class was not observed, the value of this index was highest among all sites studied $\left(\mathrm{J}^{\prime}=0.88\right)$. Another indicator used to analyze the Carabidae assemblage was the degree of species dominance $(\lambda)$. This parameter assigns a lower weight to the occurrence of rare species, paying greater attention to common species, and takes on higher values in communities dominated by one or several species. The highest value of this index was recorded at site $1(\lambda=0.58)$ where only one eudominant ( $P$. cupreus) was found; its contribution to the assemblage was 633 individuals ( $75.7 \%$ of the assemblage). The lower the value of this index, the more equal distribution of individuals among species. The lowest values of $\lambda$ were observed at two sites: $3(\lambda=0.12)$ and $2(\lambda=0.15)$. Not all dominance classes were found at these sites but the proportions of individual species recorded there were relatively equal. Huruk (2006) obtained similar results, which was related to the dominant contribution of one species. The sites that were characterized by the highest value of the dominance index, that is, they were dominated by one or two species, exhibited the lowest values of the diversity indices: site $1\left(\lambda=0.58 ; \mathrm{H}^{\prime} \ln =1.03\right)$ and site $2\left(\lambda=0.55 ; \mathrm{H}_{\text {ln }}^{\prime}=0.94\right)($ Fig. 10).

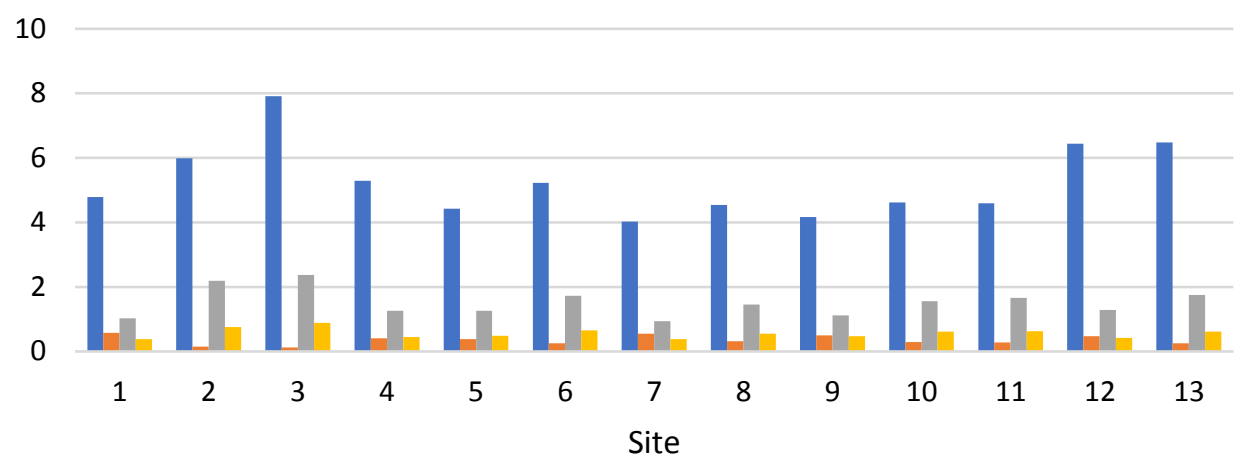

Margalef index d $\quad$ Simspon index $\lambda \quad$ Shannon index H'In $\square$ Pielou index J'

Figure 10. Indices of $\alpha$-diversity: species diversity of Margalef $(d)$, Shannon $\left(H^{\prime}{ }_{l n}\right)$, Simpson concentrate of dominance $(\lambda)$ and Pielou's Evennes $\left(J^{\prime}\right)$

Application of cultivation protection products can be another factor determining the qualitative and quantitative structure of ground beetles. In the studied material, samples were only taken from sites subjected to various agronomic practices. Due to the fact that no comparative observations were conducted based on control samples (i.e. without application of insecticides, for instance), one cannot determine the direct effect of anthropogenic factors on the occurrence of beetles.

As evidenced by research, changes in agricultural practices beneficially affecting the diversity of Carabidae include, among others, reduced use of pesticides and organic farming (Andresen and Eltun, 2002; Koss et al., 2005), but also changes in cultivation practices (Andersen, 2003) and reduced herbicide application (Thorbek and Bilde, 2004). The effect of insecticides (deltamethrin) was investigated by Kaczmarek (1992) and Aleksandrowicz (2002) who showed chemical treatments to adversely influence 
assemblages of ground beetles. Intensively cultivated potato plantations create adverse habitat conditions for most carabids (Werling and Gratton, 2008).

Nonetheless, not always does the impact of agronomic practices on the Carabidae structure cause a decrease in biodiversity. The studies by Kosewska et al. (2013) and Nijak et al. (2013) revealed that chemical protection in integrated potato cultivation does not affect adversely the preservation of the diversity of ground beetles. On the other hand, Kosewska et al. (2014) demonstrated that integrated cultivation protection can contribute to increased diversity of Carabidae. Insecticide application was not shown to have an adverse effect, but herbicide and fungicide application proved to have a significant impact on the structure of ground beetles.

Habitat factors, such as adjacent biocenoses, are an important element affecting the occurrence of Carabidae in cultivation fields. As demonstrated by Weibull et al. (2003), the vicinity of diverse biocoenoses has a major importance for the preservation of biodiversity of ground beetles in conventional cultivations. In most cases, the investigated cultivation sites in the Subcarpathian region were characterized by substantially diverse natural landscape in the form of bordering or adjacent field trees and shrubs, meadows, and forests. Among the study areas, only sites 8 and 9 bordered exclusively with agriculturally used areas. Potato cultivations located in the surroundings of low diversity habitats were characterized by the occurrence of a smaller number of both beetle species and individuals. Site 9 where the lowest number of species and a relatively low number of individuals were recorded was surrounded by cultivations of another potato cultivar and oilseed rape cultivations. In turn, the number of species and individuals was observed to increase at site 8 that also bordered with agricultural cultivations. This could have been associated with the type of the adjacent cultivation. The fields bordering with this site were sown with maize, rye, and wheat. Unlike potato cultivations, monocotyledonous cultivations are characterized by a high and dense canopy. Agronomic practices essentially involve soil preparation before seeding and harvest itself; these factors create more favorable living conditions for Carabidae than in the case of root cultivations, which is confirmed by the research conducted by Kinnunen and Tiainen (1999), Kosewska et al. (2008), Gailis and Turka (2014), and Jasiński et al. (2015). Potential microclimatic conditions prevailing not only in cultivation fields, but also in biocoenoses adjacent to them, influence the distribution of species of different moisture preferences. Dry-loving species were found in 6 cultivations studied and among them the highest percentage was shown at site 9. The presence of xerophiles can be explained, among others, by the similarity to bordering habitats (also potato cultivations), their low diversity (oilseed rape cultivations), and also more intense sun exposure. No moisture-loving species were observed there. In turn, among all study areas the highest proportion of moisture-loving species was observed at site 9 whose surroundings were most strongly diversified compared to the other sites, in particular in terms of moisture (shrubs, pastures, a meadow, a stream, ponds).

Moreover, the sites where the present study was carried out were characterized by agricultural production conducted in small-area farms which differ from large-area plantations (the largest potato cultivationping area -70 ares). The mosaic agricultural landscape specific for the Subcarpathian region promotes the preservation of biodiversity. Comparative studies of the Carabidae species composition and numbers of individuals occurring in cultivation fields and adjacent areas indicate that edge habitats are of essential importance in agroecosystems. Such habitats are generally characterized by a smaller number of recorded individuals and a higher number of identified species 
(Thienemann's rule). Conscious shaping of agricultural landscape by preserving marginal habitats, field margins, and tree stands promotes the maintenance of biodiversity in an agro-ecosystem (Twardowski and Pastuszko, 2008; Szafranek and Woszczyk, 2012; Konieczna et al., 2015).

\section{Conclusions}

The following most frequently occurring species: H. rufipes, $P$. melanarius, and $P$. cupresus, can be considered to be typical for agriculturally used areas, including potato cultivations. These are species with wide ecological tolerance and lower susceptibility to anthropogenic pressure.

On the basis of the results obtained, it cannot be said that the intensity of chemical treatments related to potato protection affects the number and biodiversity of ground beetles.

On the other hand, the structure of neighboring arable fields and the presence of forest and midfield afforestations plays an important role. In this mean the maintenance and appropriate management of diverse biocoenoses in agricultural space contribute to increase diversity Carabidae in agrarian areas.

To better understand the impact of the agricultural environment on the structure of Carabidae, it would be necessary to analyze both the impact of individual environmental factors as well as the impact of the use of individual fertilizing and crop protection products. This type of research should be carried out under controlled conditions (controlled and examined samples) and outside production farms (experimental plots).

Acknowledgements. The authors would like to thank Mesdames Paulina Żuk, Alicja Szczepańska, Kinga Ochał, Anna Wrona, Aneta Kapałowska, Katarzyna Kolebuk, Monika Kubas, Aneta Kapałowska, Alicja Szczepańska, Barbara Zyma, Małgorzata Żądło, and Anna Tokarczyk as well as Mr. Jarosław Kot for their participation in field work.

\section{REFERENCES}

[1] Aleksandrowicz, O. (2002): Influence of Decis spraying on the community structure and species composition of beetles (Insecta: Coleoptera) on a potato field. - Baltic Journal of Coleopterology 2(2): 145-153.

[2] Aleksandrowicz, O. P. (2004): Ground beetles (Carabidae). - In: Bogdanowicz, W., Chudziak, I., Pilipiuk, I., Skibińska, E. (eds.) Fauna Polski - Charakterystyka i Wykaz Gatunków. Muzeum i Instytut Zoologii PAN, Warszawa. (in Polish).

[3] Andersen, A., Eltun, R. (2002): Long-term developments in the carabid and staphylinid (Col., Carabidae and Staphylinidae) fauna during conversion from conventional to biological farming. - Journal of Applied Ecology 124: 51-56.

[4] Andersen, A. (2003): Long-term experiments with reduced tillage in spring cereals. II. Effects on pests and beneţcial Insects. - Cultivation Protection 22: 147-152.

[5] Bale, J. S., Masters, G. J., Hodkinson, I. D., Awmack, C., Bezemer, T. M., Brown, V. K., Butterfield, J., Buse, A., Coulson, J. C., Farrar, J., Good, J. E. G., Harrington, R., Hartley, S., Jones, T. H., Lindroth, R. L., Press, M. C., Symioudis, I., Waltt, A. D., Whittaker, J. B. (2002): Herbivory in global climate change research: direct effects of rising temperature on insect herbivores. - Global Change Biology 8(1): 1-16. 
[6] Baranová, B., Fazekašová, D., Jászay, T., Manko, P. (2013): Ground beetle (Coleoptera: Carabidae) community of arable land with different cultivations. - Folis faunistica Slovaca 18(1): 21-29.

[7] Basedow, T., Borg, Å., de Clercq, R., Nijveldt, W., Scherney, F. (1976): Studies on the occurence of Carabidae in European wheat fields. - Entomophaga 21(1): 59-72. (in German).

[8] Borowski, J., Łęgowski, D., Mazur, S., Perliński, S., Skłodowski, J., Smoleński, M. (1996): Impact of the nun moth control treatments on some groups of forest epigeic arthropods. Proc. Int. Conf. „Intefrated management of forest Lymantriidae”. March. 27-29. 1996. Warsaw-Sękocin (Poland): 149-186.

[9] Bukejs, A., Petrova, V., Jankevica, L., Volkov, D. (2009): Carabid beetles (Coleoptera: Carabidae) of Latvian agrocenoses: review. - Acta Biologica Universitatis Daugavpiliensis 9(1): 79-88.

[10] Cinītis, R. (1962): Carabid beetles in agrobiocenosis of potato field. - Latvijas Entomologs 5: 25-28. (in Russian).

[11] Clark, M., Luna, J. M., Stone, N. D., Youngman, R. R. (1993): Habitat preference of generalist predators in reduced-tillage corn. - Journal of Economic Entomology 28: 404416.

[12] Czechowski, W. (1981): Ground beetles (Carabidae, Coleoptera). - Fragmenta faunistica 10(12): 193-216. (in Polish).

[13] Fedorko, J. (1983): The dominance and species diversity structure of ground beetles (Col., Carabidae) in potato fields in Bonin near Koszalin. - Biuletyn Instytutu Ziemniaka 30: 117126. (in Polish).

[14] Gailis, J., Turka, I. (2014): The diversity and structure of ground beetles (Coleoptera: Carabidae) assemblages in differently managed winter wheat fields. - Baltic Jornal of Coleopterology 14(1): 33-46.

[15] Hůrka, K. (1996): Carabidae of the Czech and Slowak Republics. - Kabourek, Zlin.

[16] Huruk, S. (2002): The carabid beetles (Coleoptera, Carabidae) in annual field crops on podsolic soils. - Rocznik Świętokrzyski. Seria B. Nauki Przyrodnicze 28: 39-52. (in Polish).

[17] Huruk, S. (2006): Comparison of structure of carabid (Coleoptera: Carabidae) communities of hay meadows and adjacent cultivated fields. - Entomological News 25(1): 9-23. (in Polish).

[18] Huruk, S., Barševskis, A. (2014): Characterisation of ground beetles (Carabidae, Coleoptera) of the Holy Cross Mountains. - Wydawnictwo Emporium, Kielce. (in Polish).

[19] Huruk, S., Huruk, A., Barševskis, A., Wróbel, G., Bochenek, W. (2014): Carabidae (Coleoptera) selected forest environments inhabiting the area of the Integrated Natural Environment Monitoring Station in Szymbark. - Proceedings of ECOpole 8(1): 161-172.

[20] Irmler, U. (2003): The spatial and temporal pattern of carabidbeetles on arable fields in northern Germany (Schleswig-Holstein) and their value as ecological indicators. Agriculture, Ecosystems \& Environment 98: 231-256.

[21] Jasiński, M., Twardowski, M., Tendziagolska, E. (2015): Organic cultivations as reservoir for beneficial epigeal arthropods. - Journal of Research and Applications in Agricultural Engineering 60(30): 125-130.

[22] Juen, A., Steinbergen, K. H., Traugott, M. (2003): Seasonal change in species composition and size distribution of epigeic predators in a small field. - Entomol Gener 26(4): 259-275.

[23] Kaczmarek, S. (1992): The influence of "Decis 2.5 EC" on Carabidae potato crop. - Polish Journal of Entomology 61(3-4): 125-129. (in Polish).

[24] Karg, I. (1976): Colorado beetle in agrocenoses of the Central Wielkopolska. - Polish Ecological Studies 2: 63-86.

[25] Kinnunen, H., Tiainen, J. (1999): Carabid distribution in a farmland mosaic: the effect of patch type and location. - Annales Zoologici Fennici 36(3): 149-158. 
[26] Konieczna, K., Olbrycht, T., Wojciechowicz-Żytko, E., Wilk, E. (2015): Effect of agrotechnical measures on the abundance of ground beetles (Coleoptera, Carabidae) in selected cultivations. - Episteme 26(2): 337-315. (in Polish).

[27] Kosewska, A., Nietupski, M., Laszczak-Dawid, A., Ciepielewska, D. (2008): Assemblages of epigeic carabid beetles (Col. Carabidae) in some agricultural biocenoses. - Progress in Plant Protection/ Postępy w Ochronie Roślin 48(4): 1304-1308.

[28] Kosewska, A., Nijak, K. (2012): Structure analysis of carabid beetles (Col., Carabidae) assemblages in integrated and organic potato management. Short communictaion. Biuletyn Instytutu Hodowli i Aklimatyzacji Roślin 265: 157-164.

[29] Koss, A. M., Jensen, A. S., Schreiber, A., Pike, K. S., Snyder, W. E. (2005): Comparison of predator and pest communities in Washington potato fields treated with broadspectrum, selective, or organic insecticides. - Environmental Entomology 34: 87-95.

[30] Koval, A. G. (1999): Contribution to the knowledge of carabids (Coleoptera, Carabidae) preying on Colorado potato beetles in the potato files in Transcarpathians. - Entomological reviews 78(3): 527-536.

[31] Koval, A. G., Guseva, O. G. (2008): Structure of the Ground Beetle (Coleoptera, Carabidae) Complexes in Potato Field Agrocenoses on Different Soils in Northwestern Russia. - Entomological Review 88(3): 269-276.

[32] Koval, A. G. (2012): Studies of Adaptation of Carabid Beetles (Coleoptera, Carabidae) to Feeding on the Colorado Potato Beetle, Leptinotarsa decemlineata Say (Coleoptera, Chrysomelidae) in Agrocenoses of Potato and Other Cultivations. - Entomological Review 92(6): 633-641.

[33] Kromp, B. (1990): Carabid beetles (Coleoptera, Carabidae) as bioindicators in biological and conventional farming in Austrian potato fields. - Biology and Fertility of Soils 9: 182187.

[34] Kromp, B. (1999): Carabid beetles in sustainable agriculture: a review on pest control efficency, cultivation impacts and enhancement. - Agriculture, Ecosystems and Environment 74(1-3): 187-228.

[35] Krzysztofiak, L. (2001): Ground beetles (Col., Carabidae) of the Wigry National Park. Rocz. Augustowsko - Suwalski. Rocz. 1: 55-65. (in Polish).

[36] Leśniak, A. (1997): Methods of analysis of ground beetle (Col., Carabidae) assemblages in zooindication of ecological processes. - Evaluation of forest ecosystems by zooindication methods. Warszawa: Wyd SGGW: 29-41.

[37] Magurran, A. E. (2004): Measuring Biological Diversity. - Oxford: Blackwell Publishing Company.

[38] Nijak, K. (2005): Carabidae in sugar beet and potato cultivations. - Progress in Plant Protection / Postępy ochr. Roślin 45(2): 950-953. (in Polish).

[39] Nijak, K., Kosewska, A., Kordan, B. (2013): Comparison of carabid beetles (Col., Carabidae) assemblages in integrated and organic potato management. - Progress in Plant Protection / Postępy ochr. Roślin 53(1): 64-69. (in Polish).

[40] Nijak, K., Kosewska, A., Topa, E. (2014): Influence of plant protection on ground beetles (Col., Carabidae) assemblages in potato cultivations. - Zagadnienia Doradztwa Rolniczego 1(75): 66-74. (in Polish).

[41] Oberholzer, F., Frank, T. (2003): Predation by the Carabid beetles Pterostichus melanarius and Poecilus cupreus on Slugs and Slug eggs. - Biocontr. Sci. And Technology 1: 99-110.

[42] Pałosz, T. (1995): Intensive technologies in agriculture in relation to the ground beetle fauna. - Ochrony Roślin 39(5): 8. (in Polish).

[43] Rondon, S., Pantoja, A., Hagerty, A., Horneck, A. D. (2013): Ground beetle (Coleoptera: Carabidae) populations in commercial organic and conventional potato production. Florida Entomologist 96(4): 1492-1499.

[44] Schmidt, M. H., Lauer, A., Purtauf, T., Thies, C., Schaefer, M., Tscharntke, T. (2003): Relative Importance of Predators and Parasitoids for Cereal Aphid Control. - Biological Sciences 270(1527): 1905-1909. 
[45] Sosnowska, D., Pruszyński, S., Lipa, J. (2009): Development of methods and insecticides for control of Colorado potato beetle (Leptinotarsa decemlineata Say). - Progress in Plant Protection / Postępy ochr. Roślin 49(2): 565-576. (in Polish).

[46] Stachowiak, M. (2008): Systematic review of ground beetles of Poland (Coleoptera, Carabidae). - http://www.entomo.pl/coleoptera/carabidae/index.php.[dostęp: 09.03.2019].

[47] Sunderland, K. D. (2002): Invertebrate pest control by carabids. - In: Holland, J. M. (ed.) The Agroecology of Carabid Beetles. Intercept, Andover, UK.

[48] Szafranek, P., Woszczyk, K. (2012): Diversity and abundance of ground beetles (oleoptera: Carabidae) occurring on red beet (Beta vulgaris L.) cultivated under conventional and organic systems. - Nowości Warzywnicze/Vegetable Cultivations News 54-55: 107-112. (in Polish).

[49] Szewkienicz, A., Olbrycht, T. (2012): Ecological potato culture as a refuge of ground beetles (Col., Carabidae). - Zeszyty Naukowe PTIE i PTG Oddział w Rzeszowie 15: 95100. (in Polish).

[50] Szyszko, J. (1997): Carabids as an efficient indicator of the quality and functioning of forest ecosystems useful in forestry management. Evaluation of forest ecosystems by zooindication methods. - Warszawa: Wyd SGGW: 42-60.

[51] Thiele, H. U. (1977): Carabid beetles in their environments - a study on habitat selection by adaptations in physiology and behavior. - Springer-Verlag, New York.

[52] Thienemann, A. (1920): The basics of biocenotics and Monard faunistic principles. Festschrift Zschokke Basel 4: 1-14. (in German).

[53] Thorbek, P., Bilde, T. (2004): Reduced numbers of generalist arthropod predators after cultivation management. - Journal of Applied Ecology 41: 526-538.

[54] Traugott, M. (1998): Larval and adult species composition, phenology and life cycles of carabid beetles (Coleoptera: Carabidae) in an organic potato field. - European Journal of Soil Biology 34(4): 189-197.

[55] Trojan, P. (1980): Ecology. - Wyd. IV. PWN, Warszawa. (in Polish).

[56] Trojan, P. (1998): New prospects for entofaunistic studies. - Entomol News 17 Supl.: 137155. (in Polish, English abstract).

[57] Twardowski, J. P., Pastuszko, K. (2008): Field margins in winter wheat agrocenosis as reservoirs of beneficial ground beetles (Col., Carabidae). - Journal of Research and Applications in Agricultural Engineering 53(4): 123-127. (in Polish).

[58] Varvara, M. (2010): The genus Carabus (Coleoptera: Carabidae) in somne potato cops from Romania, 1978-1999. - Muzeul Olteniei Craiova. Oltenia. Studii şi comunicşri. Ştiinţele Naturii 26(2): 137-146.

[59] Ward, M. J., Ryan, M. R., Curran, W. S., Barbercheck, M. E., Mortensen, D. A. (2011): Cover cultivations and disturbance influence activity-density of weed seed predators Amara aenea and Harpalus pensylvanicus (Coleoptera: Carabidae). - Weed Science 59: 76-81.

[60] Weibull, A. C., Östman, Ö., Granqvist, Å. (2003): Species richness in agroecosystems: the effect of landscape, habitat and farm management. - Biodiversity and Conservation 12: 1335-1355.

[61] Werling, B. P., Gratton, C. (2008): Influence of field margins and landscape context on ground beetle diversity in Wisconsin (USA) potato fields. - Agriculture, Ecosystems and Environment 128: 104-108.

[62] Wiltshire, C. W., Hughes, L. (2000): Spatial Dynamics of Predation by Carabid Beetles on Slugs. - Journal of Animal Ecology 69(3): 367-379.

[63] Zhang, J., Drummond, F., Liebman, M. (1998): Effect of cultivation habitat and potato management practices on the population abundance of adult Harpalus rufipes (Coleoptera: Carabidae) in Maine. - Journal of Agricultural Entomology 15(1): 63-74. 